Sustainable and socially just transition to a post-lignite era in Greece: a multi-level perspective

\author{
Alexandros Nikas ${ }^{a *}$, Hera Neofytou ${ }^{a}$, Anastasios Karamaneas ${ }^{a}$, \\ Konstantinos Koasidis ${ }^{a}$, and John Psarras ${ }^{\text {a }}$ \\ ${ }^{a}$ School of Electrical and Computer Engineering, National Technical University of \\ Athens, Athens, Greece \\ * (Corresponding Author) Alexandros Nikas, Management and Decision Support \\ Systems Laboratory, School of Electrical and Computer Engineering, National \\ Technical University of Athens, Iroon Politechniou 9, 157 80, Athens, Greece, e-mail: \\ anikas@epu.ntua.gr,telephone:+30210772 3612
}




\title{
Sustainable and socially just transition to a post-lignite era in Greece: a multi-level perspective
}

\author{
Lignite has long dominated Greece's electricity system, boosting economic \\ growth and energy security, given the abundant domestic resources. In line with \\ its national and international commitments to climate action and sustainable \\ development, the country is currently facing the urgent need to transform its \\ energy system, overcome its technological lock-ins, and transition to a low- \\ carbon economy. Drawing from the need to secure a sustainable transition that \\ considers the impacts of a lignite phase-out on local economies, this study builds \\ upon the Multi-Level Perspective framework and further focuses on the phase- \\ out of the dominant fossil fuel, rather than solely exploring the phase-in of new \\ technologies. By delving into the landscape that established lignite as the \\ mainstream energy resource in Greece, as well as the factors sustaining its \\ dominance despite niche technologies and innovations challenging the regime, \\ we discuss how the envisaged decarbonization can be socially just and effective \\ across multiple sustainability dimensions.
}

Greece; multi-level perspective; systems of innovation; just transitions; lignite; coal; sustainable development; renewable energy; NECP

\section{Introduction}

In the last decades, more than $80 \%$ of global electricity generation originated from fossil fuels (IEA 2018), with coal being the backbone of power generation systems, and electricity accounting for a quarter of global greenhouse gas (GHG) emissions (Tranberg et al. 2019). In EU countries, $21.5 \%$ of the electricity produced came from solid fuels (mainly lignite and coal), in 2016, which are responsible for the majority of power generation-related $\mathrm{CO}_{2}$ emissions. Therefore, considering also the increasing energy demand, a strategy aiming to reduce GHG emissions should focus, among others, to decarbonize the electricity sector by phasing out fossil fuels and introducing greener alternatives. 
In 2017, Greece was responsible for approximately $2.2 \%$ of $\mathrm{CO}_{2}$ emissions from fossil fuels in EU countries, even though its electricity production accounts for less than $0.2 \%$ of total EU generation (IEA 2019). This means that the operations of the power sector are highly emissions-intensive, contributing $623 \mathrm{~g} \mathrm{CO}_{2} / \mathrm{kWh}$ in 2016, compared to almost half (295.8 $\mathrm{g} \mathrm{CO}_{2} / \mathrm{kWh}$ ) of the EU average (EEA, 2018), a significant contribution considering the country's socioeconomic share in the region. Latest statistics (IEA 2017) show that Greece's electricity system is coal-intensive, with lignite accounting for $34 \%$ of total production, followed by natural gas $(31 \%)$. Another significant aspect of the electricity system is that a number of islands are not interconnected with the mainland grid, thereby addressing their electricity needs via operation of oil (diesel)-fired plants. The country has a very long tradition of lignite extraction: the Greek lignite-mining industry is one of the sector's leaders in Europe, and longstanding experience in mining operations has introduced important achievements (Kavouridis 2008). Heavy reliance on lignite can be largely attributed to the abundant indigenous reserves and thus energy security and low energy costs can be achieved.

On the other hand, lignite mining and combustion have many adverse impacts on health, not only for residents nearby extraction areas, but also for the total population. According to the World Health Organization, seven million people died in 2012, as a result of exposure to air pollution (Dam et al. 2017). Lignite is considered one of the world's environmentally most hazardous fuel (Arapostathis and Fotopoulos 2019). A diversity of scenarios and pathways are proposed towards mitigating the GHG emissions associated with power generation. This study aims to examine historical development of the Greek electricity system towards assessing the potential for decarbonization by gradually shutting down lignite plants and increasing capacity of 
renewable energy sources, in a progressive coal phase-out, based on the country's pledges and recently announced plans. Given its role in the country's economy and energy security, this would entail a smooth transition, including new policies and adoption of new technologies. The trajectory towards this transition is investigated through the historical development of the Greek electricity system by determining which landscape factors have affected this process and how new low-carbon technologies, or niches, have commenced to replace some of the incumbent polluting electricity generation methods of the regime. This is accomplished by implementing the Multi-Level Perspective (MLP) framework, as thoroughly described in Section 3.

Our aim is to help understand how a low-carbon transition of the Greek energy system to a sustainable post-lignite era can be achieved. This study presents several aspects of the Greek electricity system, divided into two time periods, 1990-2008, and 2009-2017, orienting on the mark of the economic recession in Greece, which caused significant changes in energy use. The analysis is based on the Multi-Level Perspective (Rip and Kemp 1998; Geels 2002) framework, with the aim to shed light on the technological transformations from a socio-technical perspective. As such, the analysis is divided into three levels, the regime, landscape factors, and niche technologies.

This research is developed in six sections. Section 2 further delves into the background of the study, discussing the importance of a transition to a post-lignite era in Greece. Section 3 discusses the use of the Multi-Level Perspective framework in this domain; while Section 4 presents the analysis of the Greek electricity system regime as well as the landscape factors affecting it, in two time periods. Section 5 one presents the considered niche technologies that can replace conventional power plants, followed by their main benefits. Section 6 section draws from the findings to discuss where we currently stand, what is the institutional response to the outlined challenges, how the 
latter can be just, and what the impact of the discussed lignite phase-out can be on sustainability. Finally, Section 7 summarizes the conclusions of our study, followed by limitations and prospects.

\section{Lignite and other conventional sources in Greece: a 'dirty' lifecycle}

\subsection{The importance of a lignite phase-out}

There are various arguments for closing and replacing the lignite power plants operating in Greece, by other technologies; these are mainly of economic, climate/environmental and societal/health reasons. Here, we start by examining major socioeconomic and environmental aspects associated with lignite use per lifecycle stage (Table 1). These stages consist of the construction of the plant; the mining, processing and transportation of the necessary fuel; and power generation. Across all stages, lignite use creates numerous jobs; however, the environmental costs are significant. For lignite, we use a Levelized Cost of Electricity (LCOE) of €55/MWh (Roinioti and Koroneos 2019).

Table 1. Lignite power plant lifecycle $\mathrm{CO}_{2}$ emissions and external costs

\begin{tabular}{|c|c|c|c|c|c|c|}
\hline Lifecycle Stages & $\begin{array}{c}\mathrm{CO}_{2} \\
\text { emissions } \\
(\mathrm{kg} / \mathrm{MWh})\end{array}$ & $\begin{array}{c}\text { Climate } \\
\text { Change } \\
\text { External Cost } \\
(€ / \mathrm{MWh})\end{array}$ & $\begin{array}{c}\text { Direct } \\
\text { employment } \\
\text { (Job- } \\
\text { years/TWh) }\end{array}$ & $\begin{array}{c}\text { Indirect } \\
\text { employment } \\
\text { (Job- } \\
\text { years/TWh) }\end{array}$ & $\begin{array}{c}\text { Induced } \\
\text { employment } \\
\text { (Job- } \\
\text { years/TWh) }\end{array}$ & $\begin{array}{c}\text { Total } \\
\text { employment } \\
\text { (Job- } \\
\text { years/TWh) }\end{array}$ \\
\hline $\begin{array}{l}\text { Power Plant } \\
\text { Construction }\end{array}$ & 30 & 0.57 & 14.6 & 9 & 4.5 & 28.1 \\
\hline $\begin{array}{l}\text { Lignite mining, } \\
\text { processing \& } \\
\text { transportation }\end{array}$ & 20 & 0.38 & 119.5 & 39.3 & 84.8 & 243.6 \\
\hline $\begin{array}{l}\text { Power } \\
\text { Generation }\end{array}$ & $1,230.00$ & 23.37 & 104.3 & 19.8 & 54.2 & 178.3 \\
\hline Total & $1,280.00$ & 24.32 & 238.4 & 68.1 & 143.5 & 450 \\
\hline
\end{tabular}

Continuous exploitation of lignite has resulted in enlargement and depth increase (over 200 meters) of the mines, rendering them unstable and difficult to manage. This has resulted in several landslides during the last decade, some of which have occurred nearby some villages and settlements of Western Macedonia (Zevgolis, 
Deliveris, and Koukouzas 2019). Similar incidents have occurred in Poland, another (hard) coal-dependent country, sometimes corroding nearby roads (Bednarczyk 2017). Furthermore, coal excavation has been correlated with the increase of seismicity in nearby regions (Mirek K. and Mirek J. 2011).

Operation of lignite plants poses a threat to climate, biodiversity and well-being, since operational procedures evoke emissions of noxious gases in the atmosphere, which the EU has intensified efforts to restrict through regulations. Directive 2010/75/EU established targets for $\mathrm{SO}_{2}, \mathrm{NO}_{\mathrm{x}}$ and dust emissions for conventional production sources. Sulfur dioxide is considered responsible for increased mortality caused by cardiovascular and respiratory problems (Wu et al. 2020), while nitrogen oxides, apart from health issues, are related to several environmental problems, including acid rain, formation of photochemical smog and creation of fine particles (PM) (He et al. 2019). Furthermore, lignite combustion is intertwined with the emission of several pollutants aside from $\mathrm{CO}_{2}, \mathrm{SO}_{2}$ and $\mathrm{NO}_{\mathrm{x}}$, called polycyclic aromatic hydrocarbons (PAHs) and considered toxic and mutagenic, potentially with carcinogenic effects on humans and various living organisms (Nádudvari et al. 2018). All emissions may cause externality costs, which can reach up to $5 € / \mathrm{MWh}$ in the case of the Western Macedonia plants (Papagiannis et al. 2014).

Carbon dioxide aside, and in accordance with the aforementioned directive, Greece developed the 2015 Transitional National Emission Reduction Plan (TNERP), setting progressive emission targets for lignite plants from 2016 to 2020 with the obligation to perform actions to reduce emissions on a level of $200 \mathrm{mg} / \mathrm{Nm}^{3}$ for $\mathrm{SO}_{2}$ and $\mathrm{NO}_{\mathrm{x}}$. In 2018, Amyntaio, Kardia, Agios Dimitrios, Melitis and Megalopoli power plants released reports (Ministry of Energy 2018a, 2018b, 2018c, 2018d, 2018e, 2018f) on environmental parameters of monthly operations (Table 2; Figure 1). Results show 
Melitis and Megalopoli plants have already reached their targets; contrary to Agios Dimitrios units, since the implementation of a dry flue-gas desulphurization process in not feasible for all units; while Amyntaio and Kardia plants perform poorly, as operating on a limited, high-emitting basis and not bound by the same targets

With TNERP ending in 2020, there are concerns over Greece achieving its respective Sustainable Development Goal (SDG) of the 2030 Agenda for Sustainable Development (Griggs et al. 2013) — an extension of the 2000-2015 millennium development goals for social priorities worldwide (Sachs 2012)—regarding production and consumption patterns and regulation of private actors' practices (Gupta and Vegelin 2016). This is currently the case, as reflected in the country's production-based $\mathrm{SO}_{2}$ emissions, imported $\mathrm{SO}_{2}$ emissions and nitrogen production footprint (Sachs et al. 2019). This further emphasizes importance of a phase-out of lignite, which cannot achieve sufficient levels of environmental protection, even through best-available techniques (Cikankowitz and Laforest 2013).

Table 2. Average monthly emissions by power plant

\begin{tabular}{cccc}
\hline Lifecycle Stages & $\mathrm{SO}_{2}\left(\mathrm{mg} / \mathrm{Nm}^{3}\right)$ & $\mathrm{NO}_{\mathrm{x}}\left(\mathrm{mg} / \mathrm{Nm}^{3}\right)$ & $\mathrm{PM}\left(\mathrm{mg} / \mathrm{Nm}^{3}\right)$ \\
\hline Amyntaio & 816 & 227 & 50 \\
Kardia I & 169 & 238 & 118 \\
Kardia II & 173 & 203 & 94 \\
Kardia III & 195 & 301 & 37 \\
Kardia IV & 305 & 209 & 39 \\
Agios Dimitrios & 276 & 257 & 17.6 \\
Melitis & 200 & 130 & 1.2 \\
Megalopoli A & 154 & 111 & 2.5 \\
Megalopoli B & 100 & 128 & 10 \\
\hline \multicolumn{2}{c}{ Sources: Ministry of Energy $(2018 \mathrm{a}, 2018 \mathrm{~b}, 2018 \mathrm{c}, 2018 \mathrm{~d}, 2018 \mathrm{e}, 2018 \mathrm{f})$}
\end{tabular}




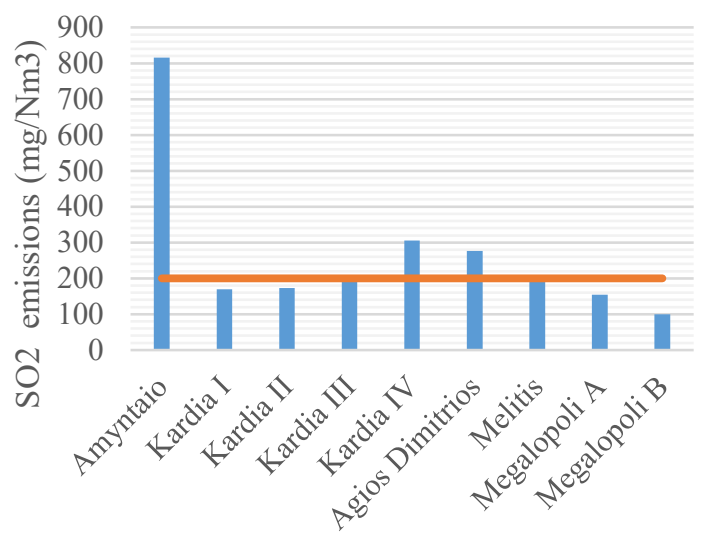

2018 average of monthy emissions

Power Plants

(a)

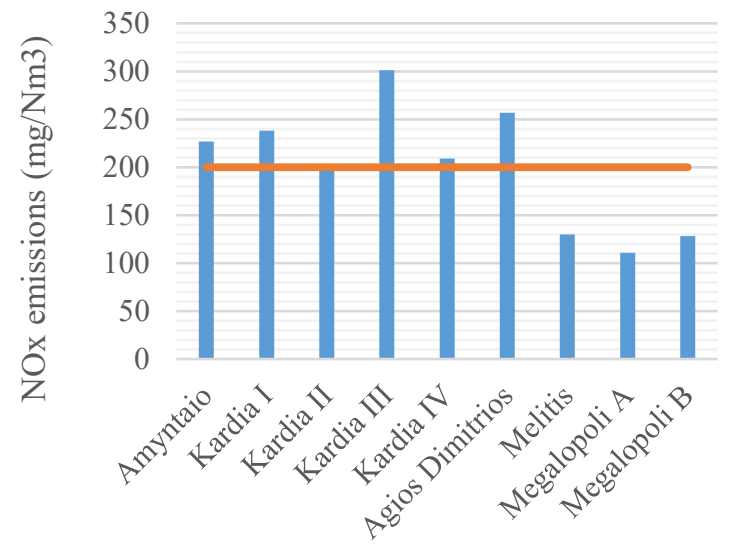

2018 average of monthy emissions

TNERP baseline

Power Plants

(b)

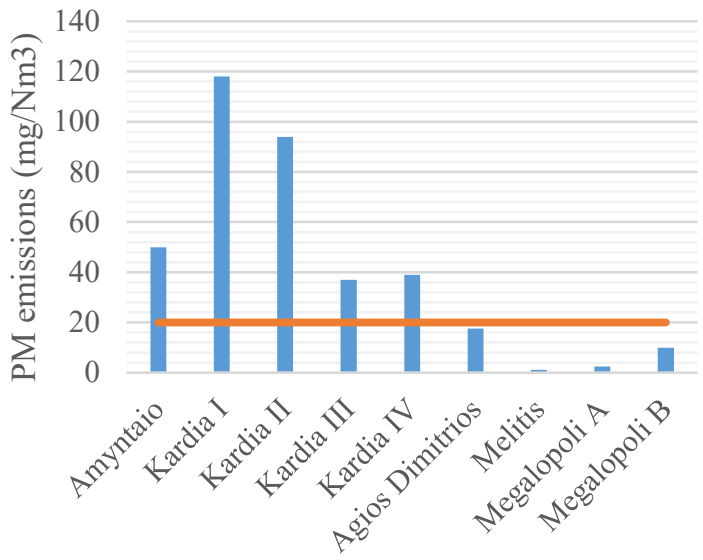

2018 average of monthy emissions

TNERP baseline

Power Plants

(c)

Figure 1. Monthly average $\mathrm{SO}_{2}(\mathrm{a}), \mathrm{NO}_{\mathrm{x}}$ (b) and dust (c) emissions for 2018

Source: Ministry of Energy (2018a, 2018b, 2018c, 2018d, 2018e, 2018f) and the 2015 TNERP; own elaboration 


\subsection{Other fossil fuels}

Diesel, a fossil fuel with high transportation capacity, is mainly used for power generation in the numerous non-interconnected islands. A major concern lies in its carbon footprint: the $\mathrm{CO}_{2}$ emissions traced in the different lifecycle stages of oil use for power generation, along with their externality costs for climate change, are displayed in Table 3.

Table 3. Diesel power plant lifecycle $\mathrm{CO}_{2}$ emissions and external costs

\begin{tabular}{ccc}
\hline Lifecycle Stages & $\begin{array}{c}\mathrm{CO}_{2} \text { emissions } \\
(\mathrm{kg} / \mathrm{MWh})\end{array}$ & $\begin{array}{c}\text { Climate Change External } \\
\text { Cost }(€ / \mathrm{MWh})\end{array}$ \\
\hline Power Plant Construction & 1.65 & 0.03 \\
Crude Oil extraction \& & 7 & 0.13 \\
Processing & 13 & 0.25 \\
Crude Oil Transportation & 42 & 0.8 \\
Crude Oil Refining & 0.58 & 0.01 \\
Fuel Oil Transportation & 780 & 14.82 \\
Power Generation & 844.23 & 16.04 \\
Total & Sources: Georgakellos (2006, 2010, 2012), Jungbluth (2007)
\end{tabular}

Diesel combustion in the country's power generation mix is also associated with employment benefits (Kis, Pandya, and Koppelaar 2018), as presented in Table 4, and an LCOE of $76.28 € / \mathrm{MWh}$.

Table 4. Jobs created by a diesel power plant

\begin{tabular}{cc}
\hline Lifecycle Stage & Job-years/TWh \\
\hline Materials extraction \& beneficiation & 5.4 \\
Power Plant Manufacturing & 6.48 \\
Construction/Installation & 21.6 \\
Fuel Transportation & 11.52 \\
Operation & 97.2 \\
Maintenance & 7.2 \\
Total & 149.4 \\
\hline
\end{tabular}

Source: Strantzali, Aravossis, and Livanos (2017)

Finally, natural gas is increasingly used for electricity generation in the country, which however exploits negligible amounts of natural gas resources (Newman 2013). Despite gaining ground as a cheap alternative to lignite and potential solution for the intermittency of a wide-scale RES deployment, backed by its competitiveness for 
energy storage (Elliott 2016), further increase of natural gas use could make Greece heavily dependent on imports to satisfy demand, and therefore potentially vulnerable to economic and political pressure (Roupas, Flamos, and Psarras 2011; Antosiewicz et al. 2019). However, natural gas produces less emissions in comparison with lignite and fuel oil, as shown in Table 5.

Table 5. Natural Gas power plant lifecycle $\mathrm{CO}_{2}$ emissions and external costs

\begin{tabular}{ccc}
\hline Lifecycle Stages & $\begin{array}{c}\mathrm{CO}_{2} \text { emissions } \\
(\mathrm{kg} / \mathrm{MWh})\end{array}$ & $\begin{array}{c}\text { Climate Change External Cost } \\
(€ / \mathrm{MWh})\end{array}$ \\
\hline Power Plant Construction & 1.81 & 0.03 \\
Natural Gas extraction \& & 1.51 & 0.03 \\
Processing & 3.37 & 0.06 \\
Natural Gas Transportation & 490 & 9.31 \\
Power Generation & 496.69 & 9.44 \\
Total & & $2007 ;$ ritsche, Rausch and Schm
\end{tabular}

Sources: (Bauer 2008; Dones et al. 2007; Fritsche, Rausch, and Schmidt 2009; Georgakellos

2010, 2012)

Despite its large share in the national energy mix, natural gas (with an LCOE of $€ 87 / \mathrm{MWh}$ ) is associated with lower employment benefits (Roinioti and Koroneos 2019), compared to lignite and diesel (Table 6).

Table 6. Jobs created from a natural gas power plant

\begin{tabular}{ccccc}
\hline $\begin{array}{c}\text { Direct } \\
\text { Employment } \\
\text { Factors }\end{array}$ & $\begin{array}{c}\text { Direct (Job-years/ } \\
\text { TWh) }\end{array}$ & $\begin{array}{c}\text { Indirect (Job-years/ } \\
\text { TWh) }\end{array}$ & $\begin{array}{c}\text { Induced (Job-years/ } \\
\text { TWh) }\end{array}$ & \multicolumn{2}{c}{ Total (Job-years/ } \\
TWh)
\end{tabular}

\section{Methodological approach}

The MLP, originally developed by Rip and Kemp (1998) and further developed by Geels (2002), consists of an analytical framework to study sociotechnical transitions and understand innovation systems. The MLP focuses on the creation of qualitative scenarios to examine the interactions and dynamics between three different levels: the landscape (macro-level), the regime (meso-level) and the niches (micro-level). 
On the micro-level, niches provide the environment for radical innovations to be created and developed (Schot 1998), and progressively breach to the meso-level disturbing the balance of the socio-technical regime, an extension of the technological regime (Nelson and Winter 1982). Inside the socio-technical system, social groups, actors and practices or structures are interlinked (Geels 2005b), determining the natural trajectories caused by the dynamic relationships following a specific set of rules. The meso-level is situated inside the exogenous environment of the macro-level, formed by the sociotechnical landscape, which influences broader sociotechnical development.

Even though the MLP focuses on the transition towards sustainable development (Geels 2011), several studies deal with cases deriving from different sectors. Congdon, Shouls, and Curtis (1997) examined the small-area health and mortality of England and Wales. On a similar aspect of public health and personal hygiene, Geels (2005a) studied the transition in water supply as a process of society-technology co-evolution. The necessity for coexistence and flexibility between the niches and the mainstream context was stressed by Smith (2007), who analyzed the green niches of eco-housing and organic food.

On the other hand, Geels (2005c) presented three historical case studies regarding the transport sector, to showcase technological substitution following landscape development and wider transformation as a result of problems in the regime. Building on this Geels (2002) also examined an interesting example of interactions between the niche and the regime furthering the argument that effective diffusion of niches could happen by progressively changing and coexisting with the regime. Nykvist and Whitmarsh (2008) expanded the niche concept to include numerous innovations driving the transition of the transport sector in the UK and Sweden: since policy measures had little effect relative to the growth in demand, the transition of the existing 
regime was based on technological improvements of vehicles; sustainable models of travel, e.g. public transport; and travel planning with emphasis on the implementation of information and communications technologies. These approaches differed from a classical approach of the niche, such as the transition to a floating grain elevator in the port of Rotterdam in 1901 (Van Driel and Schot 2005), where technological innovation created pressure on the regime, even though there was no pressure from the sociotechnical landscape. Necessity for such expansions in transport is due to the existence of multiple regimes, which in some cases contain local elements contributing to the automobility regime seeming fairly stable in contrast to other sectors (Geels 2012).

Even though the transport sector presents differences from other sectors, lessons learnt from such case studies could be used in the transition towards low-carbon economies. Indicatively, McDowall (2014) examined possible hydrogen-based transition scenarios to a low-carbon UK economy, with explicit reference to hydrogen fuel cell vehicles.

In low-carbon transitions, the MLP has been used in numerous case studies providing valuable theoretical insights. Sluisveld et al. (2017) fed MLP-based narratives to integrated assessment models, to build a case study for Europe, regarding the European Unions' $80 \%$ emission reduction objective for 2050 . On the same axis, Geels, McMeekin, and Pfluger (2018) combined quantitative models with the MLP to create socio-technical scenarios for the UK electricity sector. The MLP approach helped explore problems of social acceptance and political feasibility in low-carbon transitions, further elaborating on the introduction of politics in the MLP from Geels (2014), who focused on the role of actors instead of green niches, concluding that the decline of existing fossil fuels in the regimes should be further considered. Similarly, Rogge, Pfluger, and Geels (2018) also coupled quantitative systems modeling with the MLP to 
study the transition of the German electricity system towards renewable energy, drawing from the typologies of Geels and Schot (2007). Moallemi et al. (2017) addressed theoretical limitations by creating a framework to explain the specific dynamics of the phase-in of renewables in India's electricity system, by combining the MLP with the Multi-Pattern Approach (de Haan and Rotmans 2011), a conceptual framework of driving forces of transformative change (Frantzeskaki 2011), the actoroption framework (Yücel 2010) and tools for integrated sustainability assessment (Weaver and Rotmans 2006). Finally, Verbong and Geels (2007) used the MLP approach in the Dutch electricity system to explain how the regime, analysed in three different periods, is undertaking a progressive transition driven by liberalization and Europeanization rather than diffusion of niche technologies; since RES deployment is low compared to other European countries, they suggested that add-on technology and adjustments on existing techniques of the regime could result in substantial environmental benefits. This observation leads to the conclusion that the MLP places significant focus on technological niches as the main locus for regime change in the transition process (Berkhout, Smith, and Stirling 2004; Geels 2011). However, effort should also be placed on the transformation of the regime and not just the niches (Geels 2014) or to expanding the existing approach for niches (Nykvist and Whitmarsh 2008).

Here, acknowledging the complexity of interactions between these three levels and between policies themselves (Oikonomou, Flamos et al. 2012; Oikonomou, Flamos, and Grafakos 2014), we build upon these ideas by using the MLP framework to study historical development of the transition of the Greek electricity system towards decarbonization, considering the transformation of the existing regime, driven by the phase-out of lignite, rather than simply focusing on the phase-in of niche technologies. We also delve into the landscape factors influencing the system, to determine how 
establishment of niche technologies depend on these factors. Landscape factors can hinder niche development, but they can also generate severe barriers for the continuation of the regime, creating a friendlier setting for the penetration of niche technologies (Köhler et al. 2019). The analysis of the progress that has been achieved so far will provide valuable insights into the main drivers and difficulties leading or hindering the transition, as well as shed light on pathways to be followed after the examined period to reach the envisaged targets in a socially just manner.

\section{The Greek regime and landscape factors}

A brief look at the events preceding the examined period, for which there is little data availability and consistency (Doukas et al. 2007), shows that the first power generation unit was installed in 1889; in 1950, the Public Power Company (PPC) was established to render electricity widely available, and operated the first lignite combustion power unit in Aliveri; the first hydroelectric plants were constructed near rivers Agras, Ladonas and Louros in 1955; new diesel units were constructed to supply electricity to non-interconnected islands (including Crete) (Papadopoulos 2018) in 1956; and exploitation of another lignite reserve started in 1969 in Megalopolis (IENE 2012); with the first wind farm being constructed in Kythnos island, in 1980 (Fotiadi 2009).

\subsection{The calm before the economic storm}

\subsubsection{Regime}

In the first period (1990-2008), electricity consumption in Greece was steadily increasing (Figure 2a), mainly due to economic development, population increase and temperature rise (Asimakopoulos et al. 2012); electricity generation followed a similar

pattern (Figure 2b). In 2008, electricity consumption nearly doubled compared to 1990, while production increased by $82 \%$. Electricity production from coal accounted for $72 \%$ 
of the total production at the beginning of this period, progressively decreasing to $52 \%$ at the end of the period, with natural gas gaining ground (22\%) (IEA 2017). By 1990, twenty coal combustion units had been constructed, while one had already closed. During 1990-2008, three more units were constructed, and total installed capacity was 4,776MW. Figure 2c illustrates total installed capacity per year for each technology (conventional and RES) for both the interconnected and the non-interconnected system.

The first natural gas combustion plant was installed in Lavrio, Attica, in 1996, with a capacity of 174MW (Kaldellis et al. 2005). The installation was an important milestone for the Greek energy sector, due to hitherto exclusive dependence on lignite combustion. The use of natural gas partially undermined the country's energy independence but produced less CO2 emissions compared to lignite. During this period, nine plants were installed with a total capacity of 2,794MW of (LAGIE 2019a).

Another important contributor to electricity production was hydro plants, which can be divided based on their capacity, to small and large plants. According to Law 3468/06, small hydro plants are considered renewable sources. During this period, large hydro plants accounted for 3,017MW (TEE 2016) and combined with the small units averaged a percentage of $8 \%$ of total production (IEA 2017). Moreover, four diesel plants of 698MW in total, operated to produce electricity (LAGIE 2015).

A significant characteristic of the system was that 33 islands in the Aegean were not interconnected with the mainland system and thus 35 diesel units, of 1,367MW totally, operated independently, to cover local electricity needs (RAE 2001). The noninterconnected island power systems (NIIPSs) comprise a significant part of the Greek energy sector, accounting for $10 \%$ of electricity consumption and serving $15 \%$ of the nation's population (Hatziargyriou et al. 2017). Diesel plants, from both interconnected and non-interconnected systems, averaged $18 \%$ of production (IEA 2017). 


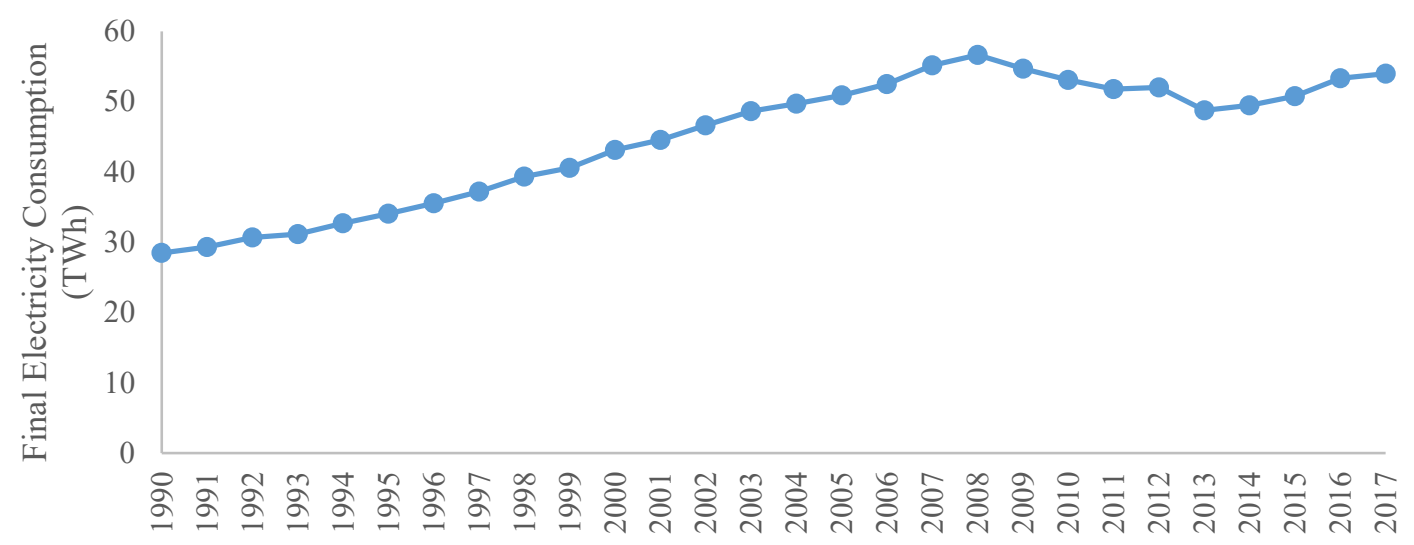

Years

(a)

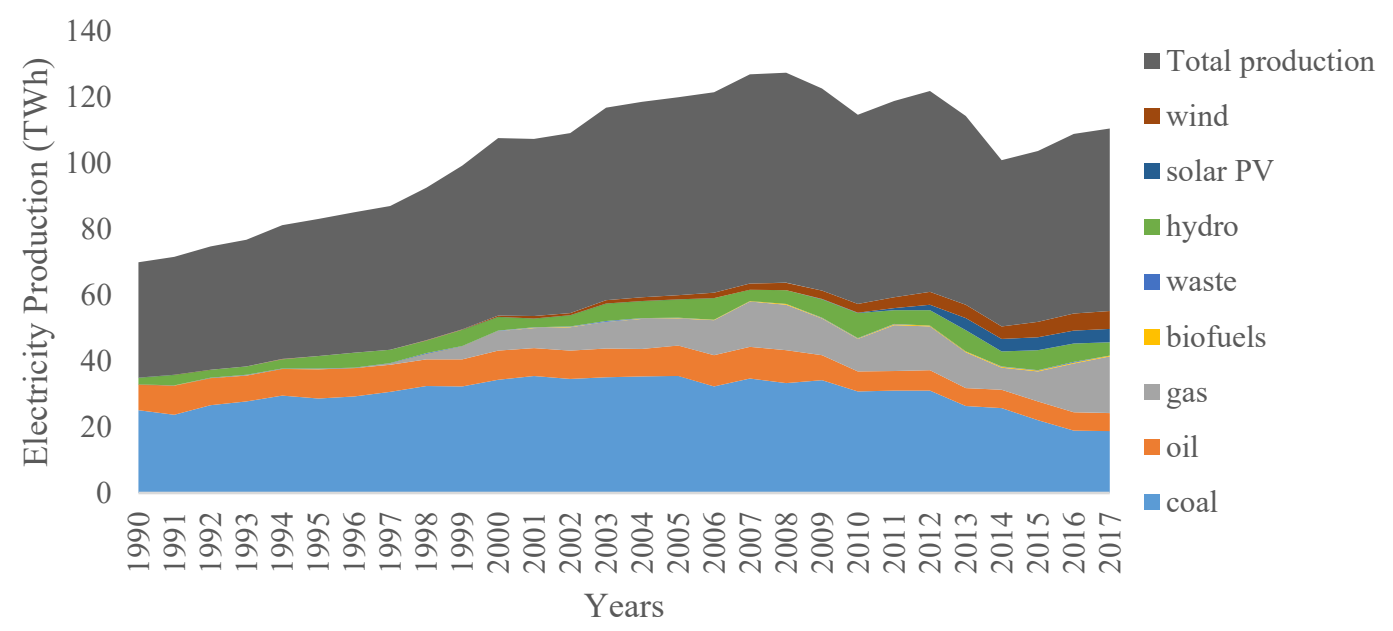

(b)

25

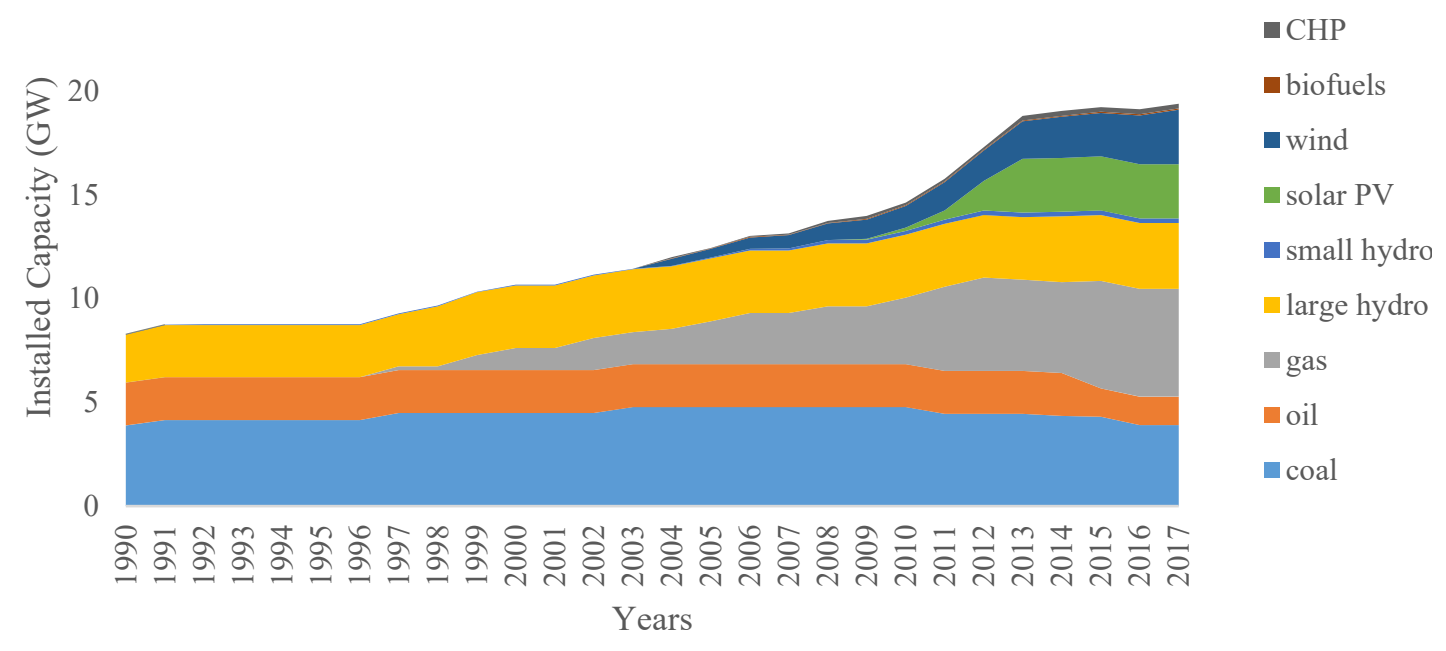

(c)

Figure 2. Electricity consumption (a), production (b) and total installed capacity (c) in Greece, 1990-2017 
At the beginning of this period, liberalization of the RES market began in 1994 (Agoris et al. 2004), in a first attempt to establish a greener energy mix. In 2006, Greek legislation integrated a framework for penetration of PV parks into the electricity mix (Giannini et al. 2015), considering Greece is amongst the European countries with the highest amounts of solar radiation (Celik, Muneer, and Clarke 2009). In 1999, an impressive growth of wind power was observed (Kaldellis 2005), signifying its penetration into the electricity market and the start of large-scale renewable energy generation in Greece. Sequentially, energy independence was increased, mitigating the negative effect of introducing natural gas in the electricity sector. The share of wind farms, accounting for $0.01 \%$ at the beginning of this period, steadily rose to $3.5 \%$ (IEA 2017); total capacity of wind farms at the end of the period was 791MW (LAGIE 2019c). Small hydro plants had a capacity of 158MW (LAGIE 2019c); while biofuels contributed $0.3 \%$ of electricity production, in 2008 (IEA 2017). The first biomass plant for electricity generation was constructed in 2001 (IEA 2017), combusting agricultural waste for electricity generation rather discarding it, thereby contributing to more efficient waste management and emissions-free energy production.

PPC was the sole owner of the electricity transmission system in 2007 . The system was composed by $11,500 \mathrm{~km}$-long lines, consisting of $66 \mathrm{kV}$ single-circuit lines as well as $150 \mathrm{kV}$ and $400 \mathrm{kV}$ single- and double-circuit lines (Lioutas et al. 2007), with the latter transferring energy produced in northern Greece towards the centre and south, where most of the electric load was concentrated (Orfanos et al. 2019). At the time, southern Peloponnese consisted mostly of $150 \mathrm{kV}$ lines, which transferred the energy produced by Megalopolis 1 and 2 (Lioutas et al. 2007).

The main actor in the Greek electricity system for several years had been PPC, the biggest electric power producer and supplier in Greece-responsible today for 
approximately $68 \%$ of total installed capacity, consisting of conventional thermal, hydroelectric and RES units. PPC was a monopoly until 2004, after which point each non-residential consumer could select their electricity supplier. Liberalization of the electricity market was completed in 2007 when selection of supplier was extended to residential consumers (RAE 2019a).

During this period, four new companies were established to supply electricity to the market: Zenith (2000); Heron (2001); PROTERGIA (2001); and ELPEDISON (2006). Other energy players (Doukas et al. 2008), outside suppliers and producers, aimed at regulation, monitoring or support of the market and the relevant activities of the energy sector. Among them, the Regulatory Authority of Energy (RAE) and the Center for Renewable Sources and Energy Saving (CRES) are the most notable. RAE, founded in 1999, is an independent regulator for electricity and gas; while CRES is the national body for RES, rational energy use and energy saving, founded in 1987 and enjoying financial and administrative autonomy, aimed at promoting applications at national and international level and reducing the environmental burden on energy production and transport.

Other organizations contributing to the effective operation of the electricity system included the Hellenic Association of Renewable Energy Producers, a non-profit company established in 1997 comprising companies in the RES domain and aiming to promote renewables; and the Hellenic Association of Photovoltaic Companies, a nonprofit urban corporation founded in 2002 by the leading companies active in the production, trading, installation and maintenance of PV systems in Greece.

Laws, another important institutional part in any system, affect its development and define on a big scale its course. According to Law 1468/1950, the PPC had taken form in 1950 with exclusive privileges in the construction, operation and exploitation of 
hydro and thermal power plants, as well as in the transmission and distribution system. Half a century later, with Law 2773/1999, there was a first attempt to open the electricity production's market to competition by allowing individuals to produce

electricity from RES, combined heat and power and conventional sources; while RAE was formed as an independent and autonomous administrative authority to regulate the energy system and PPC transformed into an Autonomous Society. One year later, the Hellenic Transmission System Operator S.A. (HTSO) was established to operate and ensure the maintenance and development of the electricity transmission system; it was owned by the state (51\%) and the producers (49\%). The opening of the market expanded, from generation to supply, with Law 3175/2003 amending Law 2773/1999 in response to European Directive 2003/54/EC, to allow any individual domestic client to be able to choose the source of consumed energy by 2007; for non-domestic clients the option was available by 2004 . Law $3468 / 2006$ finally prioritized the injection of energy from renewable sources and independent producers, introducing net-metering; and defined a feed-in-tariff (FIT) scheme, according to the type and capacity of an installation.

\subsubsection{Landscape}

The Greek electricity regime is a complex central component of the Greek energy sector; hence, it is affected by a wide variety of exogenous landscape factors, which are of technical, social, economic and political nature. It should be noted that, in this analysis, we acknowledge that boundaries between regime and landscape can be blurry at times (Upham, Kivimaa et al. 2014): policy and regulations, in particular, can be viewed both as drivers of niche developments and as macro-level processes that relate to drivers of change originating within the regime or political settings of the landscape. 
Here, however, we consistently classify legislation as part of the Greek regime, and only highlight regulatory drivers of changes to the regime as landscape factors.

One of the main landscape factors was the abundant indigenous lignite reserves, exploiting which minimized the need for imports and therefore boosted the country's energy security. During this period, Greece was the second largest lignite producer in the EU and fourth in the world, annually mining 70Mt (Kavouridis 2008). Lignite combustion was considered a very prosperous power generation option, especially after World War II and the Greek Civil War, both of which severely deteriorated the national economy in the 1940s; and decades later was still considered a driver of economic growth and energy security, despite its footprint (Kolovos 2006). Lignite exploitation has also formed the structure of the mainland transmission grid, most of which was constructed so as for the generated electricity of the concentrated lignite plants to be easily transmitted across the country, thereby contributing to the country's technological lock-in. The latter, combined with the part $(15 \%)$ of the population being located on the non-interconnected islands (Spilanis 1999), delayed RES penetration in the Greek energy mix.

In this period, climate change also started gaining cognitive ground as one of the major problems of our society and was therefore socially and politically prioritized towards avoiding its perilous consequences. The electricity sector started showing efforts to turn to more sustainable energy resources, such as wind and solar power, and to substituting coal with natural gas. These efforts were further pushed by the EU policy framework, with the establishment of the emissions trading system (in 2005) towards the end of this first period (Neuhoff, Martinez, and Sato 2006) and with the regulations and directives for carbon-intensive sectors (van der Gaast, Oikonomou, and Flamos 2013), with which the national framework struggled to harmonize. The impact of this 
measure was visible on the Greek electricity system, unexpectedly (Papadelis, Flamos, and Psarras 2013), from its first year of implementation. As shown in Figure 2b electricity generation from lignite in 2006 decreased by $6 \%$ compared to 2005 . In 2007 , the EU also set its environmental targets for 2020, including mitigation of GHG emissions by $20 \%$, reduction of energy consumption by $20 \%$, and $20 \%$ penetration of RES in the energy mix (Da Graça Carvalho 2012). Another important milestone for the Greek electricity sector was the legislation of the 2002 national plan for reducing GHG emissions and increasing the RES share to $20 \%$ by 2010 , thereby ratifying the Kyoto agreement commitments (Chalvatzis and Hooper 2009).

The political agenda of the active governing party is usually a crucial factor influencing progress of the electricity sector. In Greece, this period followed short yet significant political uncertainty (in 1989-1990) but was marked by relative political stability, seeing two parties sequentially taking control. However, the political agenda of the governing parties, from the conservative New Democracy (1990-1993) to the center-left Panhellenic Socialist Movement (1993-2004) and back to New Democracy (2004-2007), featured varying ideological orientation regarding the energy sector, climate change aspects and diplomatic ties with neighboring countries, with different implications for energy security (Doukas, Flamos, and Psarras 2011) and choice of energy imports.

The 1999 liberalization of electricity generation (RAE 2019a) constituted another landscape factor resulting in several natural gas plants partly replacing lignite combustion. The 2003 formation of a mandatory pool system for electricity generation and wholesale supply in the mainland grid obliged all suppliers to purchase electricity from the pool and plants to operate on a bid selection basis. The option was provided to household consumers of the mainland grid three years later (Iliadou 2009). 
Regarding energy security, Greece's natural gas supply was completely dependent on imports from the Russian Federation (via the Greek-Bulgarian border) and Algeria (in liquid form) (RAE 2019b), making the country's power generation mix partially dependent on diplomatic relations with these countries. As such, Greece grew vulnerable to political and economic pressure, as such leverages have previously been used such in central and eastern European countries (Antosiewicz et al. 2019) or shifted geopolitical power in the region (Vapur and Top 2017).

Last but not least, the 2007-2008 global financial crisis gravely affected several economies (Ivashina and Scharfstein 2010) and the investment capability of many nonfinancial firms (Gao and Yun 2009); being among the countries hit hard by the recession (Nikas et al. 2019), Greece entered a long-lasting financial crisis, which however affected its electricity system (Doukas, Karakosta et al. 2014) primarily in the second period under examination.

\subsection{Post-recession developments}

\subsubsection{Regime}

After the emergence of said crisis in Greece, a reduction in energy consumption and production was observed (Figure 2). In 2009, consumption fell by $3.4 \%$ in just one year and then continued falling until 2013, reaching a 14\% reduction compared to 2008, before starting recovering in 2014; in 2017 it was only 5\% lower than in 2008 (IEA 2017). These impacts were reflected in electricity production as well; however, after 2014, when more than half of the electricity produced came from lignite, the share of lignite in the power generation mix started shrinking. At the end of this period, in 2017, the share was as low as 34\% (IEA 2017), accompanied by a respective increase in natural gas. No new lignite plants were constructed, with eight of them in fact shutting 
down. Thereafter, the remaining capacity was 3,912MW (LAGIE 2019a). Natural gas gained ground, as reflected in five new gas plants being constructed for three old ones shutting down, reaching a total capacity of 5,188MW in 2017 and a share of $31 \%$ of the electricity produced (LAGIE 2015; Argyriadis and Botanaki 2006). Large hydro plants accounted for 3,172MW during this period (TEE 2016); and several diesel units in the non-interconnected island system accounted for $10 \%$ of total production in 2017 , with only a few being replaced by renewables. In NIIPSs, heavy fuel oil electricity generation constituted $81.3 \%$, wind $13.45 \%$ and solar $5.25 \%$ of the electricity produced in 2016 (Orfanos et al. 2019), making Greece with its insufficient oil reserves heavily dependent on imports (Tsirambides and Filippidis 2012).

In 2011, the power generation mix changed drastically because of the sudden penetration of PV power plants into the grid (Kyritsis et al. 2017), contributing to energy independence and reducing emissions. RES had started having a significant role after 2009, driven mainly by increasing electricity generation from wind and solar. Small hydro plants maintained steady contribution throughout this period, yet slightly higher by about 10\% (IEA 2017). Capacity of small hydro plants in the interconnected system increased at 230MW (46\% increase) (LAGIE 2019c); hydro also emerged in the non-interconnected system having a total capacity of 1.35MW (LAGIE 2019b). Wind power accounted for $10 \%$ at the end of 2017 with a total capacity of $2,300 \mathrm{MW}$ in the interconnected (LAGIE 2019c) and 323MW in the non-interconnected system (LAGIE 2019b). PVs increased by 79\%, reaching a 7\% share in total production: in the interconnected system, there were $2,445 \mathrm{MW}$ of solar power in parks and on rooftops (LAGIE 2019c); while in the non-interconnected system solar power only reached 160MW (LAGIE 2019b). At the end of 2017, biofuels contributed about $0.56 \%$ of the electricity produced, marking a 62\% increase (IEA 2017). 
Regarding the electricity transmission system, in 2011, Law 4001/2011 transferred its management to the Greek Independent Power Transmission Operator (IPTO). Ever since, there have not been significant changes to the system, which spanned across $11,232 \mathrm{~km}$ by 2013 . The grid was mostly based on overhead $150 \mathrm{kV}$ and $400 \mathrm{kV}$ lines, whereas $66 \mathrm{kV}$ lines were used for the connection with the island of Corfu (IPTO 2019a). Moreover, the Greek system was and still is interconnected via 400kV lines with Albania, North Macedonia, Bulgaria and Turkey and via a DC line with Italy (ENTSO-E 2019).

Following market liberalization, nine private companies were established after 2009 to provide electricity services (Table 7), with the previously introduced actors still in operation.

Table 7. Electricity suppliers (2009-2017)

\begin{tabular}{cc}
\hline Name & Year of establishment \\
\hline GREEN & 2009 \\
VOLTERRA SA & 2010 \\
KEN & 2010 \\
EKO ABEE & 2011 \\
WATT \& VOLT & 2011 \\
CORAL ENERGY SA & 2012 \\
VOLTON HELLENIC ENERGY SA & 2016 \\
ELTA & 2017 \\
Natural Gas Hellenic Power Company & 2017 \\
\hline
\end{tabular}

An important event of this period is two PPC departments becoming autonomous and operating independently in 2010: IPTO became responsible for the management, operation, development and maintenance of the electricity transmission system and its interconnections; and the Hellenic Electricity Distribution Network Operator (HEDNO) responsible for the distribution network and transparent and impartial access to all users. 
As before, there were actors not falling under the categories of suppliers or producers, but operating in order to regulate, monitor or support the market and relevant activities of the energy sector. Four new ones were established in this period, with the most notable one being the Operator of the Electricity Market (LAGIE), established in 2012 to carry out the daily energy planning, maintain a special register of market participants, provide participants' information and conduct cash settlement arrangements. The Association of Photovoltaic Energy Producers, established in 2009, aimed at protecting the interests of photovoltaic energy producers; the Hellenic Association of Independent Power Producers was an initiative of the largest private electricity companies aimed at promoting the production and distribution of green electricity, as well as liberalization of the market for all primary energy commodities, development of independent electric power companies with modern facilities, and creation of new jobs; and the Hellenic Association of Electricity Trading and Supply Companies, established in 2015 to assist further development of the electricity market and promote liberalization.

Legally speaking, a pricing methodology for PV electricity was established by Law 3734/2009, which introduced a considerable decrease of FITs from 2009 to 2014 and a new scheme for the years after. General FITs, excluding PV, were redefined by Law 3851/2010, which also set a national target for the RES share in gross electricity consumption to at least $20 \%$ by 2020 . Law 4001/2011, in compliance with Directive 2009/72/EC, changed the format of the energy market introducing the ownership unbundling of the transmission and distribution networks from supply and generation by creating independent authorities for the operation, transmission and distribution of energy, and leading to the split of HTSO activities to IPTO and HEDNO. Law $4203 / 2013235$ established the transition tax of security supply causing an additional 
burden to PV installations; due to the recession and low FIT rates, many RES investments became non-viable, leading in turn to a decrease of newly installed PV capacity. Law 4254/2014 once again redefined FITs, establishing the annual limit of 200MWp to be compensated by the existing FIT scheme until 2020. Law 4342/2015 integrated Directive 2012/27/EU, defining a roadmap for 20\% energy efficiency (Forouli et al. 2019). Law 4336/2015 dictated that no company should produce more than $50 \%$ of the annual electricity production and imports. The compensation system based on FITs was replaced, via Law 4414/2016, by the Feed-in-Premium system, where a differential increase based on the type of the installation was calculated on top of the market price. Law 4425/2016 reorganized the energy market by regulating the establishment and operation of the Energy Exchange, after the implementation of Law 4389/2016, which introduced PPC's obligation to sell energy to competitors at belowcost prices to limit the company's dominance and strengthen competition. In 2016, PPC also came to an agreement with China Machinery Engineering Corporation for the construction of a second lignite plant in the region of Meliti in Western Macedonia, Meliti II (Tzogopoulos 2017), raising doubts about the country's determination to deliver on its energy and climate commitments (Nikas, Ntanos, and Doukas 2019). Development progress of this plant, however, remained in a premature phase (Nikas et al. 2018). Law 3468/2006 was amended in 2017 to allow virtual net-metering for production on a different installation from consumption. Directive 2012/27/EU was amended by the Energy Efficiency Directive (2018/2002), establishing new 2030 targets, also obliging energy companies to help customers achieve $1.5 \%$ energy efficiency annually, but this had not yet been incorporated in the national framework by 2017. Finally, the National Energy and Climate Committee was established in 2017 with a main objective to create a National Energy and Climate Plan (NECP). 


\subsubsection{Landscape}

The starting point of this period is the beginning of the financial crisis in Greece, which started in the fall of 2009 (Gibson, Hall, and Tavlas 2012) as a debt crisis, leading to the reduction of electricity consumption, as well as to arrears on utility bills, causing liquidity problems for PPC (Azam et al. 2016). The financial crisis, which had a grave impact on the Greek economy and society, also affected power generation (Doukas, Tsiousi et al. 2014), since energy demand in industry and households dropped significantly during this period; while, due to financial hardship, many households were unable to support energy saving investments (Spiliotis, Arsenopoulos et al. 2020).

In comparison with most European countries, the recession in Greece significantly affected the fiscal agenda in almost every aspect of political action-and thereby political stability. The most evident example was the implementation of the three Memoranda of Understanding (MoU) between the national government and the EU, the International Monetary Fund and the European Central Bank, establishing various measures in order for the Greek economy to achieve a government budget surplus, by imposing austerity measures (Koukiadaki and Kretsos 2012) and affecting many public and private sectors, including the energy sector. For instance, the MoU required partial privatization of several public companies, including PPC (Hatalis 2012); liberalization was completed in 2011 with the establishment of HEDNO and IPTO (Danias, Kim Swales, and McGregor 2013). In 2012 and following little-if any-improvement of the country's economy, the second MoU led to abatement of RES investments, suspending the improvement of the national energy mix, and to legislation of various measures deemed to render RES investments less profitable (Eleftheriadis and Anagnostopoulou 2015). According to the third MoU, signed in 2015 towards legislating fiscal measures for further confronting the debt crisis (Kotroyannos et al. 2017), in order for the liberalization of the energy system to be completed, no company 
should produce and import more than $50 \%$ of Greece's electricity until 2020, while PPC was obliged to auction some of its productive power plants (Konstantinidis and Vlachou 2016).

The 2009 National Renewable Energy Action Plan as part of the European Union's effort to reduce GHG emissions by 2020 (Sakellaridis et al. 2011) contrasted PPC investigating construction of three new lignite plants, Ptolemaida V, Meliti II and Agios Dimitrios VI and subsequent increase of the dominating presence of lignite in the Greek energy mix.

Another important factor affecting energy policy lies in social protest movements. Despite growing concerns of climate change and voices against lignite exploitation, there were several communities in Greece that strongly opposed installation of wind plants, claiming wind turbines create visual nuisance and deteriorate the natural beauty of the landscape, further coupled with concerns over ecosystem disturbance and overall interventions necessary for the installation stage of a wind plant.

In the course of the period 2012-2014, there were various legislations undermining the rapid growth of RES investments, and especially investments in PV installations, such as an immediate freeze of licensing procedures; a new tax in 2013, passing part of installation costs to electricity consumers; and two consecutive decreases on FIT schemes in 2014 contributed to halting PV installation growth (Giannini et al. 2015; Papadelis, Stavrakas and Flamos 2016).

In 2013, the EU ETS entered its third, more radical phase, during which an EUwide cap was set, and the electricity generation sector was required to buy all of its emissions allowances (Bel and Joseph 2015), in a push for renewables. In 2015 and 2016, the ground-breaking Paris Agreement resulted in a commitment to action towards 
limiting global temperature increase to well below $2^{\circ} \mathrm{C}$ compared with pre-industrial levels (Falkner 2016).

In 2017, the EU established the Platform on Coal Regions in Transition to assist lignite-dependent countries to shut down their lignite plants without creating turbulence to local economies relying on lignite mining and exploitation (Collins 2019). In Greece, this venture pertains to the regions of Western Macedonia and Megalopolis.

\section{Niche: renewable and emerging technologies}

In Greece, lignite still constitutes the most important indigenous energy source, significantly contributing to the development of the energy sector, affecting economic development given its competitive costs compared to other imported fuels and the jobs created in mining and electricity generation (Tourkolias et al. 2009). Urban and less developed regions around mines have gradually attracted more people and been helped thrive (Kordas 2006). Aside from development of local societies, financial benefits of local lignite utilization can also be reflected in electricity prices, which indicatively in 2005 were $52 \%$ lower than the European average, and the circumvention of exchange losses (Kaldellis, Zafirakis, and Kondili 2009).

Empirical research shows that lignite is intertwined with socio-economic benefits, contributing to economic growth and employment (Badera and Kocoń 2014); even if this causality is not always bidirectional, there are concerns over closing extraction mines negatively impacting lives at the local scale and the contributions of miners, their families and people employed in related services (Gurgul 2011). This is especially true for local economies in Greece: in Megalopolis, indicatively, population remained in stagnation until the underground reserves were discovered in the 1970 s and the start of unprecedented economic growth for the city (Kaldellis, Kapsali, and Katsanou 2012). 
Replacement of lignite fire plants should therefore be realized by means of investments that counterbalance losses in development and economy. RES installations should allow for replacing carbon-intensive energy sources, mainly drawing from their potential to reduce emissions and lead to energy savings, but also to create new, green work opportunities to mitigate decrease in mining and other traditional jobs (Witajewski et al. 2019). The plan to phase out fossil fuels, which still constitute the backbone of the world's energy system, includes the transition to climate-friendly technologies like renewables.

Electricity production in the Mediterranean region is predominated by fossil fuels, even though the renewable energy potential is large and currently underexploited. Installation of large-scale RES features several advantages, such as meeting the rising electricity demand at a lower cost, sustaining long-term growth, reducing utility bills in importing countries, creating job opportunities, enhancing the quality of the environment, and encouraging energy exchange cooperation between the Mediterranean countries and the EU (Belaïd and Zrelli 2019). Here, renewable energy technologies are considered from the perspective of their lifecycle performance, thereby enabling a comparison with conventional sources.

\subsection{Wind}

Use of wind energy for electricity generation constitutes a relatively new technology, first developed in the 1980s, performing rapid growth worldwide in the last decade (Enevoldsen and Xydis 2019). There are two types of wind technologies for power generation: onshore, usually installed at high altitude like mountain tops in order to maximize the obtained energy; and offshore, installed in the sea to avoid obstacles to wind flow. The latter constitute the newest application of wind energy technology: they were introduced as recently as during the last decade (Vagiona and Kamilakis 2018), 
and are mainly installed in Northwest Europe (Arantegui and Jäger-Waldau 2018), in the North, Irish and Baltic Sea (Pantusa and Tomasicchio 2019). Given that Greece has no offshore wind parks to date, despite its rich yet underexploited shoreline, it is important to examine the effect of this technology in Greece, with offshore winds being more efficient and less stochastic and their installations featuring reduced noise and visual pollution (Vagiona and Kamilakis 2018), and with the Aegean Sea being characterized by strong winds throughout the year and low variance of wind speed and direction (Soukissian et al. 2017). Our environmental and financial analysis of wind energy plants considers only onshore wind parks, of which the socio-environmental impact, the $\mathrm{CO}_{2}$ emissions and external costs and jobs sustained per lifecycle stage are presented in Table 8. Every year, there are new park installations in Greece (Kaldellis and Apostolou 2018).

Table 8. Wind power lifecycle $\mathrm{CO}_{2}$ emissions and external costs

\begin{tabular}{ccccccc}
\hline $\begin{array}{c}\text { Lifecycle } \\
\text { Stages }\end{array}$ & $\begin{array}{c}\mathrm{CO}_{2} \\
\text { emissions } \\
(\mathrm{kg} / \mathrm{MWh})\end{array}$ & $\begin{array}{c}\text { Climate } \\
\text { Change } \\
\text { External Cost } \\
(€ / \mathrm{MWh})\end{array}$ & $\begin{array}{c}\text { Direct } \\
\text { employment } \\
(\text { Job-years/ } \\
\text { TWh })\end{array}$ & $\begin{array}{c}\text { Indirect } \\
\text { employment } \\
\text { (Job-years/ } \\
\text { TWh })\end{array}$ & $\begin{array}{c}\text { Induced } \\
\text { employment } \\
\text { (Job-years/ } \\
\text { TWh })\end{array}$ & $\begin{array}{c}\text { Total } \\
\text { employment } \\
\text { (Job-years/ } \\
\text { TWh })\end{array}$ \\
\hline $\begin{array}{c}\text { Power Plant } \\
\begin{array}{c}\text { Construction } \\
\text { Power }\end{array}\end{array}$ & 8.2 & 0.16 & 160.3 & 88.2 & 66.3 & 314.8 \\
$\begin{array}{c}\text { Generation } \\
\text { Total }\end{array}$ & 0 & 0 & 136.9 & 61.6 & 74.7 & 273.2 \\
\hline \multicolumn{2}{c}{} & 0.16 & 297.2 & 149.8 & 141 & 588 \\
\hline
\end{tabular}

The LCOE value for onshore wind parks, in good sites in Greece, can be lower than 60€/MWh, based on April 2019 action bids (New Climate Institute 2019), which is significantly lower than the LCOE of a biomass power plant or a natural gas plant.

Another promising choice for increasing penetration of wind energy in the country is the construction of hybrid power stations, which couple wind power with storage. Today, there are only two such applications in Greece, and few worldwide, due to current maturity of storage technologies (Katsaprakakis, 2016) and lack of effective financing frameworks rendering them viable and competitive (Vasilakos 2020). These 
include a wind turbine of $900 \mathrm{~kW}$ with a $160 \mathrm{kWel}$ PV installation and a battery system with a total capacity of $3 \mathrm{MW}$, in Tilos; and a $2.7 \mathrm{MW}$ wind park with two hydroelectric turbines, in Ikaria, along with a 2MW water pumping system at the lower reservoir of the hydro storage plant, for the surplus of wind energy to be stored (Kaldellis 2020).

\subsection{Solar}

Another widely exploited renewable source, solar power is exploited mainly by PV panels, and is relatively new, with broad application starting in 2008 in Europe, which had a pioneering role in its growth. Although Greece is considered an attractive solar market choice (Stavrakas, Papadelis and Flamos 2019) and, along with the broader Mediterranean region, is characterized by favorable weather (De Felice et al. 2018), PV technology become belatedly widespread in the country, compared to the rest of Europe, mainly after 2011 (Arantegui and Jäger-Waldau 2018).

Another technique for generating solar-based electricity is concentrated solar power (CSP), which depends on the thermal power of the sun, and is used almost exclusively in Spain and the USA (with a combined share of $98 \%$ of worldwide installations). Despite its weather conditions and solar radiation (Kabir et al. 2018), Greece has no CSP plants (Achkari and El Fadar 2020); the technology has low yield in Greece, except for southern locations (Zafeiratou and Spataru, 2015)—although Greek households generally exploit solar energy to produce hot water (Martinopoulos and Tsalikis 2018), with the country accounting for $0.7 \%$ of the world's solar water heating collectors, which is equivalent to the share of Japan and Italy (Ge et al. 2018). It is important to mention that there are two CSP plants under development. The first is situated in the island of Crete, in the south. The second, however, will be constructed in Florina, in the northern part of Greece that is heavily dependent on lignite (Fernández et al. 2019), showing that the region, despite lacking ideal conditions, can also host some 
CSP plants. Neither CSP plant is operative yet. Our analysis therefore focuses strictly on photovoltaics, regarding their socio-environmental impact, including $\mathrm{CO}_{2}$ emissions, external costs and jobs per lifecycle stage (Table 9).

Table 9 PV lifecycle $\mathrm{CO}_{2}$ emissions and external costs.

\begin{tabular}{|c|c|c|c|c|c|c|}
\hline $\begin{array}{l}\text { Lifecycle } \\
\text { Stages }\end{array}$ & $\begin{array}{c}\mathrm{CO}_{2} \\
\text { emissions } \\
(\mathrm{kg} / \mathrm{MWh})\end{array}$ & $\begin{array}{c}\text { Climate } \\
\text { Change } \\
\text { External Cost } \\
(€ / \mathrm{MWh})\end{array}$ & $\begin{array}{c}\text { Direct } \\
\text { employment } \\
\text { (Job-years/ } \\
\text { TWh) }\end{array}$ & $\begin{array}{c}\text { Indirect } \\
\text { employment } \\
\text { (Job-years/ } \\
\text { TWh) }\end{array}$ & $\begin{array}{c}\text { Induced } \\
\text { employment } \\
\text { (Job-years/ } \\
\text { TWh) }\end{array}$ & $\begin{array}{c}\text { Total } \\
\text { employment } \\
\text { (Job-years/ } \\
\text { TWh) }\end{array}$ \\
\hline $\begin{array}{l}\text { Power Plant } \\
\text { Construction }\end{array}$ & 104 & 1.98 & 612.2 & 333.7 & 255.6 & 1201.5 \\
\hline $\begin{array}{c}\text { Power } \\
\text { Generation }\end{array}$ & 0 & 0 & 146.8 & 56.4 & 98 & 301.2 \\
\hline Total & 104 & 1.98 & 759 & 389.4 & 353.6 & 1502.7 \\
\hline
\end{tabular}

PV power plants create the highest number of jobs per TWh for their construction and operation, with the LCOE of PV plants being lower than $70 € / \mathrm{MWh}$, since the starting level of a July 2019 auction was $0.69 € / \mathrm{MWh}$ (Jäger-Waldau 2019). PV plants also feature potential to contribute to mitigating job losses in the envisaged transition.

Furthermore, many panels are already installed on house rooftops, cultivating the conditions for an effective net-metering and decentralized generation framework (Stavrakas and Flamos 2020; Michas, Stavrakas et al. 2020). An important legislation, introduced in 2018, tried to combine PV systems with the operation of energy communities, in which a number of households can install a PV system and use the produced energy taking advantage of such a mechanism (Jager-Waldau et al. 2018).

\subsection{Biomass}

Biomass is one of the least exploited forms of RES in Greece, with a 56.5MW capacity. There are three different types of plants depending on the type of biofuel used, all associated with agriculture residue but depending on local agricultural activities: orange tree pruning biomass-fired power plants can be found only in the prefectures of Laconia 
and Argolis; the other two types orient on olive tree residue, using either the pruning or the dried pressed olive kernel (Sagani, Hagidimitriou, and Dedoussis 2019). Apart from a light footprint, biomass plants also contribute to waste management, since proper removal and disposal of agriculture waste can be a rigorous challenge for many agricultural prefectures, and biomass enables successful handling and disposal.

Emissions per lifecycle stage are displayed in Table 10, along with the jobs created. The total carbon footprint of a biomass-fired plant is evidently substantial, but biomass can be co-fired in lignite plants reducing overall emissions (Drosatos et al. 2020) and its LCOE (93€/MWh) may be considered financially viable considering the number of jobs created.

Table 10. Biomass power plant lifecycle $\mathrm{CO}_{2}$ emissions and external costs

\begin{tabular}{|c|c|c|c|c|c|c|}
\hline $\begin{array}{c}\text { Lifecycle } \\
\text { Stages }\end{array}$ & $\begin{array}{c}\mathrm{CO}_{2} \\
\text { emissions } \\
(\mathrm{kg} / \mathrm{MWh})\end{array}$ & $\begin{array}{c}\text { Climate } \\
\text { Change } \\
\text { External Cost } \\
(€ / \mathrm{MWh})\end{array}$ & $\begin{array}{c}\text { Direct } \\
\text { employment } \\
\text { (Job-years/ } \\
\text { TWh) }\end{array}$ & $\begin{array}{c}\text { Indirect } \\
\text { employment } \\
\text { (Job-years/ } \\
\text { TWh) }\end{array}$ & $\begin{array}{c}\text { Induced } \\
\text { employment } \\
\text { (Job-years/ } \\
\text { TWh) }\end{array}$ & $\begin{array}{c}\text { Total } \\
\text { employment } \\
\text { (Job-years/ } \\
\text { TWh) }\end{array}$ \\
\hline $\begin{array}{l}\text { Power Plant } \\
\text { Construction }\end{array}$ & 38.5 & 0.73 & 116.3 & 57 & 45 & 218.3 \\
\hline $\begin{array}{l}\text { Biomass } \\
\text { Production }\end{array}$ & 72.5 & 1.35 & 363.2 & 130.8 & 136.5 & 630.5 \\
\hline $\begin{array}{c}\text { Biomass } \\
\text { Transportation }\end{array}$ & 13.7 & 0.26 & & & & \\
\hline $\begin{array}{c}\text { Power } \\
\text { Generation }\end{array}$ & 0 & 0 & & & & \\
\hline Total & 124.7 & 2.37 & 479.5 & 187.8 & 181.5 & 848.8 \\
\hline
\end{tabular}

\subsection{Hydro}

Hydro power plants are separated in two major categories, based on their capacity and requirements: small (up to $10 \mathrm{MW}$ ), usually located on rivers and requiring little or no water storage and therefore no dam construction (Arribas et al. 2019); and large, usually requiring the construction of a dam of a height of 100m or more (Efstratiadis 2019). Although the process of producing electricity from hydro power is emissions-free, the construction of hydro plants is not as reflected in Table 11 . The reservoir created by the 
dam replaces a usually vast land area, which might have been the habitat of many species of flora and fauna, or even an agricultural area; therefore, the formation of a reservoir may threaten the lives of several animals and plants or even the crop yield of a region (World Commission on Dams 2000). Furthermore, dam construction may affect the quality of the river's water flowing towards the dam, while reservoir formation may erode the soil in some cases (Botelho et al. 2017; de Lima Andrade and dos Santos 2015). Nevertheless, it is noteworthy that all of the above are dependent on the topology and biodiversity of each region; the construction of a hydro plant must take into account many environmental factors, in order for it to be considered completely environmentfriendly, and its overall carbon footprint may still be considered negligible, compared to other options. Depending on size, the LCOE fluctuates from $80 € / \mathrm{MWh}$ for small to 132€/MWh for larger plants (Roinioti and Koroneos 2019).

Table 11. Hydro power lifecycle $\mathrm{CO}_{2}$ emissions and external costs

\begin{tabular}{|c|c|c|c|c|c|c|}
\hline $\begin{array}{l}\text { Lifecycle } \\
\text { Stages }\end{array}$ & $\begin{array}{c}\mathrm{CO}_{2} \\
\text { emissions } \\
(\mathrm{kg} / \mathrm{MWh})\end{array}$ & $\begin{array}{c}\text { Climate } \\
\text { Change } \\
\text { External Cost } \\
(€ / \mathrm{MWh})\end{array}$ & $\begin{array}{c}\text { Direct } \\
\text { employment } \\
\text { (Job-years/ } \\
\text { TWh) }\end{array}$ & $\begin{array}{c}\text { Indirect } \\
\text { employment } \\
\text { (Job-years/ } \\
\text { TWh) }\end{array}$ & $\begin{array}{c}\text { Induced } \\
\text { employment } \\
\text { (Job-years/ } \\
\text { TWh) }\end{array}$ & $\begin{array}{c}\text { Total } \\
\text { employment } \\
\text { (Job-years/ } \\
\text { TWh) } \\
\end{array}$ \\
\hline $\begin{array}{l}\text { Power Plant } \\
\text { Construction }\end{array}$ & 2.51 & 0.05 & 83.3 & 39.5 & 31.5 & 154.3 \\
\hline $\begin{array}{c}\text { Power } \\
\text { Generation }\end{array}$ & 0 & 0 & 95.4 & 40.2 & 54.1 & 189.7 \\
\hline Total & 2.51 & 0.05 & 178.7 & 79.7 & 85.6 & 344 \\
\hline
\end{tabular}

\subsection{Other technologies}

\subsubsection{Carbon capture and storage}

The Greek electricity sector is heavily dependent on fossil fuels and especially lignite, resulting in high GHG emissions. An interesting method for reducing $\mathrm{CO} 2$ emissions could lie in the use of carbon, capture and storage: the pre-combustion capture, the postcombustion capture and oxyfuel. The most common option is the post-combustion capture, an important aspect of which lies in the storage method: generally, there are 
three ways of storing carbon: ocean storage, geological storage and mineral carbonation; for Greece, the first method is not very prosperous, since most plants are situated in landlocked areas, far from the sea (Kelektsoglou 2018).

There exist few sites studied for the construction of geological storage plants: Prinos, in Kavala; Pentalofos and Eptachori, in Northwestern Greece; Evros, in the north east; and Vourinos in Western Macedonia; but this option is considered to have several environmental risks (Tasianas et al. 2016; Koukouzas et al. 2018; Vatalis et al. 2012).

Mineral carbonation is considered more prosperous, since Greece disposes abundant geological forms capable of this procedure, some of which include basaltic rocks found in the Pindos mountain range (Saccani and Photiades 2004), basalt in numerous Greek islands, (Mortazavi and Sparks 2004; Stouraiti et al. 2017; Bachmann et al. 2012), and ultramafic rocks in Central Greece (Magganas and Koutsovitis 2015; Koutsovitis 2012).

\subsubsection{Ocean energy}

There are various forms of exploiting the energy of seas, including tidal energy, wave energy, ocean thermal conversion and salinity gradients. In Greece, according to Nikolaidis et al. (2019), only tidal, current and wave energy can be used sufficiently.

Wave energy is one of the most abundant, frequent, periodic and easily predictable sources of energy; and could be considered as a competent alternative to fossil fuel combustion (Melikoglu 2018). Today, there is no policy for exploiting wave energy in Greece, a country with low potential, compared to other Mediterranean regions. However, there are sites that may be considered worthy of wave energy investments, with most promising candidates including Crete, Naxos and Euboia (Lavidas 2019). 
Construction of wave energy converter plants can also contribute to the creation of hundreds of new jobs in Greece, since there are plenty of potential sites.; the capital cost for these plants, however, is still much higher compared to other RES plants, but is predicted to drop by 2030 (Lavidas 2019).

Current and tidal energy applications are not thoroughly studied in Greece.

Although there is significant current activity in the south coast of Crete (Nikolaidis et al. 2019), the most studied and known example in the country is the Evoikos Gulf (Tsirogiannis, Angelidis, and Kotsovinos 2019).

\subsubsection{Hydrogen}

Another interesting option lately being investigated is the use of hydrogen for storage, especially in RES plants. Most Greek islands are not interconnected to the mainland grid; therefore, storage of renewable energy is necessary to fully exploit the maximum RES potential (Apostolou and Enevoldsen 2019). This is mainly important for the insular regions of Greece because of the oil-based electricity generation, which is quite expensive, compared to generation cost in the mainland (Kavadias, Alexopoulos, and Charis 2019), and since oil combustion produces significant amounts of CO2 emissions.

A common application of the RES-hydrogen combination lies in maximizing availability of wind parks: the abundant energy produced but not absorbed in the grid is used to produce hydrogen, which can be stored and then used by fuel cells to generate the necessary amounts of electricity for the grid, when wind power is insufficient (Apostolou and Enevoldsen 2019); this technology, along with other alternatives like batteries and compressed air energy storage (Zafeiratou and Spataru, 2019) as well as refurbishing existing turbines and using hydrogen as a fuel, can be considered for the islands' energy future. But hydrogen use can be coupled with various technologies, without significant methodological differences. The construction of fuel cell electricity 
generation plants might therefore be a very promising solution for Greece, allowing further exploitation of its high solar and wind potential.

\section{Discussion}

\subsection{Where are we now?}

Taking a closer look at the developments of the first period, we observe increasing energy demand due to the country's economic development at the time. The dominant energy source was lignite, with PPC being the main actor, as the owner of the indigenous reserves and responsible for their exploitation. Non-interconnection with islands, among others (Zafeiratou and Spataru, 2017), also slowed down penetration of RES in the energy mix: oil-based electricity generation to meet their demands remained heavily dependent on fuel imports, given the country's insufficient oil reserves (Tsirambides and Filippidis 2012).

Among the first transition attempts were the liberalization of renewables in 1994 (Agoris et al. 2004) and of the electricity sector in 1999, by allowing private investors to construct and operate power plants (Iliadou 2009). In 1999, a first increase of natural gas is observed, and so are the first wind farms. This increase of natural gas is mainly driven by private investors - most gas plants do not belong to PPC — showcasing that liberalization of the electricity sector is an important driver towards use of cleaner fuels in comparison with the lignite regime, dominating the power system at that time. In 2006, a legal framework was integrated for the penetration of PV parks into power generation (Giannini et al. 2015), resulting in the start of a remarkable boom of solar power in 2009 , when electricity production from lignite dropped for the first time. All these developments led to a greener energy mix. Earlier, in 2007, liberalization of the electricity market was completed, with the opening of the market expanding to the 
supply of electricity and not just production, in order for any individual domestic client to be able to choose their supplier-for non-domestic clients the option had been made available since 2004. Around the same time, the injection of energy produced from renewable sources and independent producers was prioritized, while FITs were established for different types and capacity; altogether marking the rise of competition in this domain.

Two intertwined factors to significantly contribute to the transition and gradual reduction of lignite were EU policies and directives, and developments in the EU ETS, triggered by the necessity to address climate change. These policies had a significant effect on the destabilization of the lignite-based regime, since a year after the launch of EU ETS in 2006, there was a drop in electricity generation from lignite by $9 \%$.

The recession in Greece, starting towards the end of 2009 (Gibson, Hall, and Tavlas 2012), as well as the implementation of the three MoU led to the reduction of electricity consumption, needs and therefore generation. In 2010, total electricity production was reduced by $6 \%$ while production from lignite dropped by almost $10 \%$ as a result of the crisis, coupled with European and national emission regulations. At the same time, among the repercussions of the crisis, households and businesses were discouraged from investing in RES installations and energy saving interventions.

Since 2012, electricity generation from lignite had declined, and until 2017 it had dropped by almost $40 \%$. This was mainly due to the ETS entering its third phase, and the age of most of the country's inefficient lignite plants. However, electricity demand increased between 2013 and 2017, reaching an overall increase of 10\%, and was mainly addressed by solar power that rose in 2012 and 2013 and then by wind and hydro. 
Another important factor that contributed to the transformation of the market, in this period, was the establishment of the organizations responsible for its regulation, monitoring and support as well as for protecting the interests of relevant stakeholders. Some factors, including regulations, enhanced the environment for RES development, for instance through the enactment of targets for green energy, energy efficiency and emissions reductions. Others, on the other hand, such as the cut of FITs and the transition tax of security of supply, halted RES penetration, with PV capacity indicatively remaining virtually the same since 2013. The negative effect of the latter was reinforced by the continued recession and societal opposition to installation of wind turbines, which remains strong in 2020.

Law 4513/2018 cultivated the conditions for the implementation of energy cooperatives in the energy system, boosting energy democracy and enabling local authorities to participate in the production of energy. In 2018, two new private suppliers entered the market and the first interconnection with non-interconnection islands in Cyclades took place.

Despite the tendency for more RES installations and the augmented emission prices, in 2013, PPC made a controversial move and announced the construction of a new lignite plant in Ptolemaida (Roumpos and Papacosta 2013), to further exploit the low-quality, domestic lignite (Kaldellis and Kapsali 2014). Today, the NECP appears to plan to build this plant and shift operation to natural gas in 2028. Moreover, the entire lignite power plant stock of the country is expected to start shutting down in 2021, a process currently expected to speed up, given two major events of 2019: first, Law $4533 / 2018$ planned the sale of two lignite units with the mining rights, in order to limit PPC's monopoly, which appeared endeavoring to auction some of its plants to private investors to reduce its debt (Naftemporiki 2019); and, second, the Prime Minister, when 
representing the country in the UN Summit for Climate Change in September 2019, announced the country's determination to shut down all lignite plants by 2028 (WWF 2019), as reflected in the NECP.

However, as discussed in Section 4, progress of the phase-out of lignite has been limited over the 37-year period examined, mainly due to the financial crisis. The small period remaining until 2028 requires that radical transformations take place to reach the desired target, potentially giving rise to social imbalances. The importance of a wellprepared and sustainable lignite phase-out is emphasized by the socioeconomic and environmental impacts of all technologies discussed in the previous sections. In the examined period, and particularly from the end of the first period, a lignite phase-out started taking place. Lignite combustion has been reduced by almost $50 \%$ in just twelve years, from 2005 to 2017 (Figure 2b). A large increase of RES generation is also observed, especially after the beginning of the second period. This phenomenon demonstrates that landscape factors like EU policy and national regulations, driven by climate change, have set serious challenges to the existing regime, leading towards a gradual lignite phase-out. At the same time, landscape factors have also created favorable conditions, e.g. legislation of financing schemes, for the phase-in of niche technologies such as wind and solar PV energy generation, which are progressively becoming part of the regime.

\subsection{A new energy and climate plan: a just transition?}

In December 2019, the Greek Government published a revised version of its initially drafted NECP in late 2018, after public consultation until mid-December 2019, featuring more ambitious targets towards climate change mitigation, with implications for most economic sectors. Among others, it aims to reduce energy consumption by promoting energy efficiency measures in households; achieve rapid penetration of 
electric cars in the transportation sector; and proceed in the longer run to interconnecting most Greek islands to the mainland electricity grid. Most importantly, the plan appears to focus on a complete lignite phase-out by 2028 , with potentially positive effects on the Greek economy. Again, national legislation acts as an important landscape driver of lignite phase-out.

Benefits of transitioning from lignite to "cleaner" energy sources aside, the NECP also raised some concerns. The promoted transition and the associated shutdown of various lignite plants may give rise to job losses and overburden local economies, which are heavily dependent on the operation of these plants, in turn leading to desolation of entire towns. Such a transition should therefore be realized while creating new job opportunities and innovatively exploiting lignite sites. A just, low-carbon transition should entail investments in clean sectors and technologies, respect human life and labor rights; be based on social dialogue among all affected; draw on socioeconomic impact assessments; and support local communities affected but illrepresented in the decarbonization agenda (Doukas et al. 2018).

In this direction and in addition to the outlined activities, local civil societies of the lignite regions (Florina, Amyntaio, Ptolemaida and Megalopolis) should be supported by the Greek Government, since the shutdown of the lignite plants is expected to severely impact employment and local economies. Towards achieving a just transition and in line with several sustainability dimensions, resources from the EU Just Transition Fund should be made available accordingly, for these communities to transform their economic and development model and maintain social cohesion. Citizen engagement can help understand how the transition can be "just" (Papada et al. 2019), building on recent analyses of the importance of social dialogue to achieve procedural and distributional justice (Gambhir, Green, and Pearson 2018) and 
gender equality (Sorman et al. 2020) in such transitions. The EU Platform on Coal Regions in Transition to support heavily coal-dependent nations assists communication among national, regional and local stakeholders regarding the modernization of these regions' economies; and enables people working in the lignite sector to obtain new skills and become capable of working in a "greener" reality (European Commission 2018). In Greece, Western Macedonia has joined the platform and receives assistance for relevant issues.

Finally, aside from climate and energy justice issues, major concerns over the country's revised NECP lie in the insufficient description of the investments required for accomplishing its targets; and in its limited consideration of the current electricity grid not being able to accommodate the ambitious increase of RES penetration in the country's energy mix, without significant and costly maintenance and expansion activities. Furthermore, as observed in Section 4, natural gas has been gaining ground more rapidly than renewables; growing dependence on natural gas to make up for cuts on lignite combustion can be considered as a delignitization pathway but not as a decarbonization way forward, especially since natural gas has been gaining ground more rapidly than renewables. This showcases that mapping the NECP in the MLP is not as straightforward, as it does not secure the country will not lock into a transition fuel regime instead of a sustainable decarbonization pathway.

\subsection{Impacts on sustainability}

Two main concerns of human society are the socioeconomic development and the mitigation of climate change. Towards this direction, in 2015, the UN established the seventeen SDGs, defined by 169 targets, emphasizing inter alia the development of every country with respect to the environment, in order to avoid further impacts of climate change (Allen, Metternicht, and Wiedmann 2016), by focusing on efficient and 
sustainable resource use (SDGs 2,6,7,12); preservation of the environment (SDGs 13,14,15); human and economic development (SDGs 1,3,4,5,8,10); and good governance and infrastructure (SDGs 9,11,16,17) (van Soest et al. 2019):

The impact of a wide-scale lignite phase-out on the SDGs was reflected in the analysis of its innovation structural elements. As a major event for the Greek economy, such a transformation will potentially affect almost every aspect of the country's development, infrastructure and governance. According to Nguyen et al. (2019), the provision of clean energy, which is the main goal of an energy transition, may result in economic growth in various regions; given Greece's high RES potential (Arabatzis, Kyriakopoulos, and Tsialis 2017), an energy transition may be beneficial for its economy and contribute to its recovery from the ongoing recession.

A transition orbiting on a lignite phase-out in parallel with technologies driven by climate action is a major step towards affordable, reliable and modern energy (Swain and Karimu 2020); this is especially true for an economy heavily locked-in like Greece. Investments in renewable energies could prove to be a significant factor of economic growth (Koçak and Şarkgüneşi 2017); for Greece, clean energy investments should attract economy-wide investments and contribute to sustainable economic growth, as well as better employment opportunities and activity rate, as pinpointed by recent modeling studies (Nikas et al. 2018); similar studies in the literature show that this can be the case for economies that are even more coal-dependent (Antosiewicz et al. 2019). The impact on local economies, hitherto revolving around lignite-fired electricity generation, however, is expected to be severe: empirical evidence suggests that miners' adaptability to different sectoral employment requirements can be very slow (Autor, Dorn, and Hanson 2016), and this is where the EU Platform on Coal Regions in Transition can contribute. 
Clean energy, economic growth and productive employment aside, the envisaged transition could lead to cleaner energy use from industries as well, thereby contributing to mitigating emissions per unit of value added; it also features significant potential as a key factor for sustainable city transformations: substituting biomass combustion for lignite use, may contribute to better waste management at the local level (Moustakas, Parmaxidou, and Vakalis 2019), in which Greece currently performs very poorly compared to other EU Member States (Noll et al. 2019). Cleaner energy alternatives will also promote responsible use of the planet's resources and abatement of the national expenditure on fossil fuels.

Last but not least, gradually shutting down lignite and mitigating emissions of various pollutants not only is directly intertwined with climate action but also features significant health co-benefits: polluted air provokes respiratory and cardiovascular problems, and phasing out lignite may help confront these issues at the local level (Samara et al. 2018).

\section{Concluding remarks}

This research aims to map the Greek electricity system from a socio-technical perspective, in order to understand how a low-carbon transition to a sustainable postlignite era can be achieved through the phase-out of lignite, rather than simply focusing on the phase-in of niche technologies. This manuscript presents several aspects of the Greek electricity system, with the 2008 economic crisis as a reference timepoint; by implementing the Multi-Level Perspective framework, the interactions and dynamics between three different levels are examined: regime, landscape and niches.

Regime analysis of the coal-intensive Greek electricity system showed that, for many years, lignite exploitation contributed to the country's socioeconomic growth. Electricity demand had been increasing until the emergence of the 2008 financial crisis. 
Climate change and respective EU policies, as well as national legal developments regarding the operation and management of the electricity system, including inter alia market liberalization, contributed to the decrease of lignite utilization for electricity generation, and to the parallel increase of renewables in the power generation mix; but an unstable regulatory framework driven by commitments to austerity-oriented reforms halted the pace of RES penetration (Nikas et al. 2019). The latter is deemed insufficient considering the national targets for environmental protection and climate action (Forouli et al. 2019). Coal phase-out should be implemented with at-scale deployment of existing and new niche technologies that can at the same time mitigate the negative impacts on employment and therefore also boost regional development. Such technologies were also analyzed, and their impacts on various dimensions were assessed to be overall positive.

The drafted and then revised Greek National Energy and Climate Plan (NECP) includes ambitious targets for climate change mitigation, with implications for almost every economic sector and aspect of the Greek society. Our research highlights that local civil societies in the lignite regions should be facilitated to transform, in order to maintain social cohesion; this support will provisionally enable achieving a just transition, in consideration of requirements for procedural and distributional justice across different income groups, labor and gender (Sari et al. 2017). Moreover, in order to address potential adverse effects of such a transition (Nikas, Ntanos, and Doukas 2019), focus should be given in the country's performance across all sustainability dimensions, emphasizing the country's development with respect to the environment, in order to avoid any further impacts of global environmental change. In careful consideration of the factors that boosted lignite as a major energy source in Greece as well as hindered attempted transformations in the past, as analyzed in this research, the 
energy transition can prove beneficial for the country's economy and contribute to its recovery from the long-lasting socioeconomic impacts of the economic crisis.

Our research can be enhanced by integrating the employed MLP framework with different Systems of Innovation tools, like Technological Innovation Systems (TIS) (Carlsson and Stankiewicz 1991), which have also been used in studies of lowcarbon transitions (e.g. Edsand 2017); acknowledging the explicit technological focus of this framework, the MLP can be used to evaluate the broader context of landscape and regime, leading to an effectively integrated framework (Markard and Truffer 2008). Furthermore, we have outlined how citizen engagement is crucial in sound, acceptable and effective policymaking, but the same can be said for science. This can also be the case in future work of our sociotechnical analysis, where stakeholders' tacit knowledge sheds light in certain qualitative aspects of a transition that are hard to identify through quantitative models (Nikas, Doukas et al. 2017; Lieu, Spyridaki et al. 2018). Another prospect, in the same direction, could be to couple these insights with models and stress-test how these can help define modeling assumptions and scenarios or vice versa (Rogge, Pfluger and Geels, 2018; van Sluisveld, Hof et al. 2018).

\section{Acknowledgement}

This research was supported by the H2020 European Commission Project "PARIS REINFORCE" under grant Agreement No. 820846. The sole responsibility for the content of this paper lies with the authors; the paper does not necessarily reflect the opinions of the European Commission 


\section{References}

Achkari, O., and A. El Fadar. 2020. "Latest Developments On TES And CSP

Technologies - Energy And Environmental Issues, Applications And Research Trends". Applied Thermal Engineering 167: 114806.

doi:10.1016/j.applthermaleng.2019.114806.

Agoris, D., K. Tigas, G. Giannakidis, F. Siakkis, S. Vassos, N. Vassilakos, V. Kilias, M. Damassiotis. 2004. An analysis of the Greek energy system in view of the Kyoto commitments. Energy policy 32 (18): 2019-2033.

Allen, C., G. Metternicht, and T. Wiedmann. 2016. National pathways to the Sustainable Development Goals (SDGs): A comparative review of scenario modelling tools. Environmental Science \& Policy 66: 199-207.

Antosiewicz, M., A. Nikas, A. Szpor, J. Witajewski-Baltvilks, and H. Doukas. 2019. Pathways for the transition of the Polish power sector and associated risks. Environmental Innovation and Societal Transitions.

Apostolou, D., and P. Enevoldsen. 2019. The past, present and potential of hydrogen as a multifunctional storage application for wind power. Renewable and Sustainable Energy Reviews 112: 917-929.

Arabatzis, G., G. Kyriakopoulos, and P. Tsialis. 2017. Typology of regional units based on RES plants: The case of Greece. Renewable and Sustainable Energy Reviews 78: $1424-1434$.

Arantegui, R. L., and A. Jäger-Waldau. 2018. Photovoltaics and wind status in the European Union after the Paris Agreement. Renewable and Sustainable Energy Reviews 81: 2460-2471.

Arapostathis, S., and F. Fotopoulos. 2019. Transnational energy flows, capacity building and Greece's quest for energy autarky, 1914-2010. Energy policy 127: $39-50$.

Argyriadis, X., and E. Bonataki. 2006. Integration of natural gas plants in the Greek electrical production system: Recursion-Technologies. Accessed January 19, 2020.

https://www.dei.gr/documents/energytec\%202006\%20argyriadis\%201.pdf.

Arribas, E. C., J. H. Lantarón, C.A. Porro, and M. J. P. Gómez. 2019. Management and operation of small hydropower plants through a climate service targeted at endusers. 2019 IEEE International Conference on Environment and Electrical 
Engineering and 2019 IEEE Industrial and Commercial Power Systems Europe (EEEIC/I\&CPS Europe).

Asimakopoulos, D. A., M. Santamouris, I. Farrou, M. Laskari, M. Saliari, G. Zanis, G. Giannakidis, K. Tigas, J. Kapsomenakis, and C. Douvis. 2012. Modelling the energy demand projection of the building sector in Greece in the 21 st century. Energy and Buildings 49: 488-498.

Autor, D. H., D. Dorn, and G. H. Hanson. 2016. The china shock: Learning from labormarket adjustment to large changes in trade. Annual Review of Economics 8: 205-240.

Azam, M., A. Q. Khan, E. Zafeiriou, and G. Arabatzis. 2016. Socio-economic determinants of energy consumption: An empirical survey for Greece. Renewable and Sustainable Energy Reviews 57: 1556-1567.

Bachmann, O., C. D. Deering, J. S. Ruprecht, C. Huber, A. Skopelitis, and S. Schnyder. 2012. Evolution of silicic magmas in the Kos-Nisyros volcanic center, Greece: A petrological cycle associated with caldera collapse. Contributions to Mineralogy and Petrology 163 (1): 151-166.

Badera, J., and, P. Kocoń. 2014. Local community opinions regarding the socioenvironmental aspects of lignite surface mining: experiences from central Poland. Energy Policy 66: 507-516.

Bauer, C. 2008. Life Cycle Assessment of Fossil and Biomass Power Generation Chains: An Analysis Carried Out for ALSTOM Power Services. Paul Scherrer Institut Villigen, Switzerland.

Bednarczyk, Z. 2017. Landslide monitoring and counteraction technologies in polish lignite opencast mines. Workshop on World Landslide Forum.

Bel, G., and S. Joseph. 2015. Emission abatement: Untangling the impacts of the EU ETS and the economic crisis. Energy Economics 49: 531-539.

Berkhout, F., A. Smith, and A. Stirling. 2004. Socio-technological regimes and transition contexts. System innovation and the transition to sustainability: Theory, evidence and policy 44 (106): 48-75.

Bhat, I. K., and R. Prakash. 2009. LCA of renewable energy for electricity generation systems - a review. Renewable and Sustainable Energy Reviews 13 (5): 10671073.

Biska, A., and N. Oikonomou. 2006. Environmental consideration of ready-mixed concrete production. Tech. Chron. Sci. J: 35-48. 
Botelho, A., P. Ferreira, F. Lima, L. M. C. Pinto, and S. Sousa. 2017. Assessment of the environmental impacts associated with hydropower. Renewable and Sustainable Energy Reviews 70: 896-904.

Carlsson, B., and R. Stankiewicz. 1991. On the nature, function and composition of technological systems. Journal of evolutionary economics 1 (2): 93-118.

Celik, A. N., T. Muneer, and P. Clarke. 2009. A review of installed solar photovoltaic and thermal collector capacities in relation to solar potential for the EU-15. Renewable Energy 34 (3): 849-856.

Chalvatzis, K. J., and E. Hooper. 2009. Energy security vs. climate change: Theoretical framework development and experience in selected EU electricity markets. Renewable and Sustainable Energy Reviews 13 (9): 2703-2709.

CIEMAT. 2004. ExternE Externalities of Energy Vol XX: National Implementation. Accessed January 19, 2020. http://www.externe.info/externe_d7/sites/default/files/vol10.pdf.

Cikankowitz, A., and V. Laforest. 2013. Using BAT performance as an evaluation method of techniques. Journal of cleaner production 42: 141-158.

Collins, C. 2019. Beyond Coal: Phase-Out Policies in the EU and Implications for the United States. A Climate Institute Publication. Accessed January 19, 2020. http://climate.org/wp-content/uploads/2019/05/Beyond-Coal-Phaseout-policiesin-the-EU-and-implication-for-the-United-States.pdf

Congdon, P., S. Shouls, and S. Curtis. 1997. A multi-level perspective on small-area health and mortality: a case study of England and Wales. International journal of population geography 3 (3): 243-263.

da Graça Carvalho, M. 2012. EU energy and climate change strategy. Energy 40 (1): $19-22$.

Dam, N., A. Ricketts, B. Catlett, and J. Henriques. 2017. Wearable sensors for analyzing personal exposure to air pollution. 2017 Systems and Information Engineering Design Symposium (SIEDS).

Danias, N., J. K. Swales, and P. McGregor. 2013. The Greek electricity market reforms: political and regulatory considerations. Energy policy 62: 1040-1047.

De Felice, M., M. B. Soares, A. Alessandri, and A. Troccoli. 2019. Scoping the potential usefulness of seasonal climate forecasts for solar power management. Renewable Energy 142: 215-223. 
de Haan, J. H., and J. Rotmans. 2011. Patterns in transitions: understanding complex chains of change. Technological Forecasting and Social Change 78 (1): 90-102. de Lima Andrade, A., and M. A. dos Santos. 2015. Hydroelectric plants environmental viability: Strategic environmental assessment application in Brazil. Renewable and Sustainable Energy Reviews 52: 1413-1423.

Dones, R., C. Bauer, R. Bolliger, B. Burger, M. F. Emmenegger, R. Frischknecht, T. Heck, N. Jungbluth, A. Röder, and M. Tuchschmid. 2007. Life cycle inventories of energy systems: results for current systems in Switzerland and other UCTE countries. Final report ecoinvent data v2.0 No. 5, Paul Scherrer Institut villigen, Swiss Centre for Life Cycle Inventories, Düberdorf, $\mathrm{CH}$.

Doukas, H., A. Flamos, and J. Psarras. 2011. Risks on the security of oil and gas supply. Energy Sources, Part B: Economics, Planning, and Policy 6(4): 417-425.

Doukas, H., A. Nikas, M. González-Eguino, I. Arto, and A. Anger-Kraavi. 2018. From integrated to integrative: Delivering on the Paris Agreement. Sustainability 10 (7): 2299.

Doukas, H., A. Tsiousi, V. Marinakis, and J. Psarras. 2014. Linguistic multi-criteria decision making for energy and environmental corporate policy. Information Sciences 258: 328-338.

Doukas, H., C. Karakosta, A. Flamos, and J. Psarras. 2014. Foresight for energy policy: techniques and methods employed in Greece. Energy Sources, Part B: Economics, Planning, and Policy 9 (2): 109-119.

Doukas, H., K. D. Patlitzianas, A.G., Kagiannas, and J. Psarras. 2008. Energy policy making: an old concept or a modern challenge? Energy Sources, Part B: Economics, Planning, and Policy 3 (4): 362-371.

Doukas, H., W. Mannsbart, K. D. Patlitzianas, J. Psarras, M. Ragwitz, and B. Schlomann. 2007. A methodology for validating the renewable energy data in EU. Renewable Energy 32 (12): 1981-1998.

Drosatos, P., N. Nikolopoulos, E. Karampinis, G. Strotos, P. Grammelis, and E. Kakaras. 2020. Numerical comparative investigation of a flexible lignite-fired boiler using pre-dried lignite or biomass as supporting fuel. Renewable Energy 145: $1831-1848$.

Edsand, H.E. 2017. Identifying barriers to wind energy diffusion in Colombia: A function analysis of the technological innovation system and the wider context. Technology in Society 49: 1-15. 
EEA (European Environment Agency). 2018. CO2 emission intensity. Accessed March 31, 2020. https://www.eea.europa.eu/data-and-maps/daviz/co2-emissionintensity-5

Efstratiadis, A. 2019. Dams and their environmental impacts in Greece: insights, problems and challenges. Accessed January 19, 2020. https://www.itia.ntua.gr/en/docinfo/1951/.

Eleftheriadis, I. M., and E. G. Anagnostopoulou. 2015. Identifying barriers in the diffusion of renewable energy sources. Energy Policy 80: 153-164.

Elliott, D. 2016. A balancing act for renewables. Nature Energy 1: 15003.

Enevoldsen, P., and G. Xydis. 2019. Examining the trends of 35 years growth of key wind turbine components. Energy for sustainable development 50: 18-26.

ENTSO-E (European Network of Transmission System Operators for Electricity). 2019. ENTSO-E Transmission System Map. Accessed January 19, 2020. https://www.entsoe.eu/data/map/.

European Commission. 2018. Coal regions in transition. Accessed January 19, 2020. https://ec.europa.eu/energy/en/topics/oil-gas-and-coal/EU-coal-regions/coalregions-transition.

Evans, A., V. Strezov, and T. J. Evans. 2010. Sustainability considerations for electricity generation from biomass. Renewable and sustainable energy reviews 14 (5): 1419-1427.

Falkner, R. 2016. The Paris Agreement and the new logic of international climate politics. International Affairs 92 (5): 1107-1125.

Fernández, A. G., J. Gomez-Vidal, E. Oró, A. Kruizenga, A. Solé, and L. F. Cabeza. 2019. Mainstreaming Commercial CSP Systems: A Technology Review. Renewable Energy 140: 152-176.

Forouli, A., N. Gkonis, A. Nikas, E. Siskos, H. Doukas, and C. Tourkolias. 2019. Energy efficiency promotion in Greece in light of risk: Evaluating policies as portfolio assets. Energy 170: 818-831.

Fotiadi, I. 2009. The slow development of wind farms. Kathimerini, May 30, 2009. Accessed January 19, 2020. https://www.kathimerini.gr/359658/article/epikairothta/ellada/me-ry8moysxelwnas-ta-aiolika-parka.

Frantzeskaki, N. 2011. Dynamics of societal transitions; driving forces and feedback loops. Doctoral Thesis, TU Delft. 
Fritsche, U., and L. Rausch. 2009. Life cycle analysis of GHG and air pollutant emissions from renewable and conventional electricity, heating, and transport fuel options in the EU until 2030. Technical Paper No. 18, The European Topic Centre on Air and Climate Change, Öko-Institut.

Gambhir, A., F. Green, and P. J. G. Pearson. 2018. Towards a just and equitable lowcarbon energy transition. Briefing Paper No. 26, Grantham Institute, Imperial College London.

Gao, P., and H. Yun. 2009. Liquidity Backstop, Corporate Borrowings, and Real Effects. Available at SSNR: https://ssrn.com/abstract=1421908.

Ge, T. S., R. Z. Wang, Z. Y. Xu, Q. W. Pan, S. Du, X. M. Chen, T. Ma, X. N. Wu, X. L. Sun, and J. F. Chen. 2018. Solar heating and cooling: Present and future development. Renewable Energy 126: 1126-1140.

Geels, F. W. 2002. Technological transitions as evolutionary reconfiguration processes: a multi-level perspective and a case-study. Research policy 31 (8-9): 1257-1274.

Geels, F. W. 2005a. Co-evolution of technology and society: The transition in water supply and personal hygiene in the Netherlands (1850-1930) - a case study in multi-level perspective. Technology in society 27 (3): 363-397.

Geels, F. W. 2005b. Processes and patterns in transitions and system innovations: Refining the co-evolutionary multi-level perspective. Technological forecasting and social change 72 (6): 681-696.

Geels, F. W. 2005c. Technological transitions and system innovations: a coevolutionary and socio-technical analysis. Edward Elgar Publishing.

Geels, F. W. 2011. The multi-level perspective on sustainability transitions: Responses to seven criticisms. Environmental innovation and societal transitions 1 (1): 2440.

Geels, F. W. 2012. A socio-technical analysis of low-carbon transitions: introducing the multi-level perspective into transport studies. Journal of transport geography 24: 471-482.

Geels, F. W. 2014. Regime resistance against low-carbon transitions: introducing politics and power into the multi-level perspective. Theory, Culture \& Society 31 (5): 21-40.

Geels, F. W., A. McMeekin, and B. Pfluger. 2018. Socio-technical scenarios as a methodological tool to explore social and political feasibility in low-carbon transitions: Bridging computer models and the multi-level perspective in UK 
electricity generation (2010-2050). Technological Forecasting and Social Change.

Geels, F. W., and J. Schot. 2007. Typology of sociotechnical transition pathways. Research policy 36 (3): 399-417.

Georgakellos, D. A. 2006. The marginal external cost of electricity coming from a typical oil power plant in Greece. Proceedings of IASME/WSEAS International Conference on Energy, Environment, and Sustainable Development. Vouliagmeni, Greece, July 11-13.

Georgakellos, D. A. 2010. Impact of a possible environmental externalities internalisation on energy prices: The case of the greenhouse gases from the Greek electricity sector. Energy Economics 32 (1): 202-209.

Georgakellos, D. A. 2012. Climate change external cost appraisal of electricity generation systems from a life cycle perspective: the case of Greece. Journal of Cleaner production 32: 124-140.

Giannini, E., A. Moropoulou, Z. Maroulis, and G. Siouti. 2015. Penetration of photovoltaics in Greece. Energies 8 (7): 6497-6508.

Gibson, H. D., S. G. Hall, and G. S. Tavlas. 2012. The Greek financial crisis: growing imbalances and sovereign spreads. Journal of International Money and Finance 31 (3): 498-516.

Griggs, D., M. Stafford-Smith, O. Gaffney, J. Rockström, M. C. Öhman, P. Shyamsundar, W. Steffen, G. Glaser, N. Kanie, and I. Noble. 2013. Policy: Sustainable development goals for people and planet. Nature 495 (7441): 305.

Gupta, J., and C. Vegelin. 2016. Sustainable development goals and inclusive development. International environmental agreements: Politics, law and economics 16 (3): 433-448.

Gurgul, H. 2011. The role of coal consumption in the economic growth of the Polish economy in transition. Energy Policy 39 (4): 2088-2099.

Hatalis, M. 2012. Greek Sovereign Debt and the Rocky Road to Recovery. Paper No. 12, Lehigh University. Accessed January 19, 2020. https://preserve.lehigh.edu/perspectives-v30/12/.

Hatziargyriou, N., I. Margaris, I. Stavropoulou, S. Papathanassiou, and A. Dimeas. 2017. Noninterconnected island systems: The Greek case. IEEE Electrification Magazine 5 (2): 17-27. 
He, S., L. Zhao, S. Ding, S. Liang, L. Dong, J. Wang, Y. Feng, and L. Liu. 2019.

Mapping economic drivers of China's NOx emissions due to energy consumption. Journal of Cleaner Production 241: 118130.

IEA (International Energy Agency). 2017. Data and statistics. Accessed January 19, 2020. https://www.iea.org/data-and-statistics.

IEA (International Energy Agency). 2018. World Energy Balances 2018. Paris: OECD Publishing.

IEA (International Energy Agency). 2019. Data and statistics. Accessed January 19, 2020. https://www.iea.org/data-and-

statistics? country $=\mathrm{GREECE} \&$ fuel $=\mathrm{CO} 2 \% 20 \mathrm{emissions} \&$ indicator $=\mathrm{CO} 2 \% 20 \mathrm{emi}$ ssions $\% 20$ by\%20energy\%20source.

IENE (Institute of Energy of South East Europe). 2012. The role of lignite power plants for further development of the electricity sector of Greece. Accessed January 19, 2020. https://www.iene.gr/energydevelopment2012/articlefiles/session2/\%CE\%9Cizan.pdf.

Iliadou, E. N. 2009. Electricity sector reform in Greece. Utilities Policy 17 (1): 76-87. IPTO (Independent Power Transmission Operator). 2019a. Monthly Energy Reports. Accessed January 19, 2020. http:/www.admie.gr/en/market-statistics/montlhyenergy-balance/.

IPTO (Independent Power Transmission Operator). 2019b. Transmission System Description. Accessed January 19, 2020. http://www.admie.gr/en/transmissionsystem/system-data-description/transmission-system-description/.

Ivashina, V., and D. Scharfstein. 2010. Bank lending during the financial crisis of 2008. Journal of Financial economics 97 (3): 319-338.

Jäger-Waldau, A., C. Bucher, K. H. B. Frederiksen, R. Guerro-Lemus, G. Mason, B. Mather, C. Mayr, D. Moneta, J. Nikoletatos, and M. B. Roberts. 2018. Selfconsumption of electricity produced from PV systems in apartment buildingsComparison of the situation in Australia, Austria, Denmark, Germany, Greece, Italy, Spain, Switzerland and the USA. 2018 IEEE 7th World Conference on Photovoltaic Energy Conversion (WCPEC) (A Joint Conference of 45th IEEE PVSC, 28th PVSEC \& 34th EU PVSEC).

Jäger-Waldau, A. 2019. PV Status Report 2019, EUR 29938 EN. Publications Office of the European Union, Luxembourg. 
Jungbluth, N., and. E. R. Dones. 2007. Sachbilanzen von Energiesystemen: Grundlagen fur den okologischen Vergleich von Energiesystemen und den Einbezug von Energiesystemen in Okobilanzen fur die Schweiz. Ecoinvent report No. 6, Swiss Centre for Life Cycle Inventories, Dübendorf, $\mathrm{CH}$

Jungmeier, G., G. Resch, and J. Spitzer. 1998. Environmental burdens over the entire life cycle of a biomass CHP plant. Biomass and Bioenergy 15 (4-5): 311-323.

Kabir, E., P. Kumar, S. Kumar, A. A. Adelodun, and K. H. Kim. 2018. Solar energy: Potential and future prospects. Renewable and Sustainable Energy Reviews 82: 894-900.

Kaldellis, J. K. 2005. Social attitude towards wind energy applications in Greece. Energy Policy 33 (5): 595-602.

Kaldellis, J. K. 2020. What Is the Wind Energy Progress in Greece? Prospects and Problems. In The Age of Wind Energy, 23-40. Springer.

Kaldellis, J. K., and D. Apostolou. 2018. Wind Power Contribution in Achieving Global Renewable Energy Targets: Current Status and Future Prospects. Renewable Energy Engineering: Solar, Wind, Biomass, Hydrogen and Geothermal Energy Systems. 3: 238-271.

Kaldellis, J. K., and M. Kapsali. 2014. Evaluation of the long-term environmental performance of Greek lignite-fired power stations. Renewable and Sustainable Energy Reviews 31: 472-485.

Kaldellis, J. K., D. Zafirakis, and E. Kondili. 2009. Contribution of lignite in the Greek electricity generation: review and future prospects. Fuel 88 (3): 475-489.

Kaldellis, J. K., G.T. Vlachos, A. G. Paliatsos, and E. M. Kondili. 2005. Detailed examination of the Greek electricity sector nitrogen oxides emissions for the period 1995-2002. Environmental Science \& Policy 8 (5): 502-514.

Kaldellis, J. K., M. Kapsali, and E. Katsanou. 2012. Renewable energy applications in Greece-What is the public attitude? Energy Policy 42: 37-48.

Katsaprakakis, D. A. 2016. Hybrid power plants in non-interconnected insular systems. Applied Energy 164: 268-283.

Kavadias, K. A., P. Alexopoulos, and G. Charis. 2019. Techno-economic evaluation of geothermal-solar power plant in Nisyros island in Greece. Energy Procedia 159: 136-141.

Kavouridis, K. 2008. Lignite industry in Greece within a world context: Mining, energy supply and environment. Energy Policy 36 (4): 1257-1272. 
Kelektsoglou, K. 2018. Carbon capture and storage: A review of mineral storage of CO2 in Greece. Sustainability 10 (12): 4400.

Kellenberger, D., H. J. Althaus, N. Jungbluth, T. Künniger, M. Lehmann, and P. Thalmann. 2007. Life cycle inventories of building products. Final report ecoinvent data v2.0 No. 7, EMPA Dübendorf, Swiss Centre for Life Cycle Inventories, Dübendorf, $\mathrm{CH}$.

Kis, Z., N. Pandya, and R. H. E. M. Koppelaar. 2018. Electricity generation technologies: Comparison of materials use, energy return on investment, jobs creation and CO2 emissions reduction. Energy policy 120: 144-157.

Koçak, E., and A. Şarkgüneşi. 2017. The renewable energy and economic growth nexus in Black Sea and Balkan countries. Energy Policy 100: 51-57.

Köhler, Jonathan, F. W. Geels, F. Kern, J. Markard, E. Onsongo, A. Wieczorek, and F. Alkemade et al. 2019. An Agenda For Sustainability Transitions Research: State Of The Art And Future Directions. Environmental Innovation And Societal Transitions 31: 1-32.

Kolovos, C. J. 2006. Technical aspects regarding the opening of a new mine with old already-existing equipment. Energy Sources, Part B: Economics, Planning, and Policy, 1(1): 1-7.

Konstantinidis, C., and A. Vlachou. 2018. Appropriating Nature in Crisis-ridden Greece: Deepening Neoliberal Capitalism, Part 2. Capitalism Nature Socialism 29 (2): 108-121.

Kordas, I. J. 2006. LIGNITE AS CONTRIBUTORY FACTOR TO REGIONAL DEVELOPMENT OF GREECE-The case of Megalopolis basin at Central Peloponese. European Regional Science Association. 46th Congress, Volos.

Korre, A., and S. Durucan. 2009. Life Cycle Assessment of Aggregates, EVA025-Final Report: Aggregates Industry Life Cycle Assessment Model: Modelling Tools and Case Studies. Waste and Resources Action Programme, Oxon.

Kotroyannos, D., S. I. Tzagkarakis, E. Mavrozacharakis, and A. Kamekis. 2017. Utopian Left-Wing Expectations and the Social Consequences of the 3rd Memorandum in Greece. European Quarterly of Political Attitudes and Mentalities 6 (2): 55-66.

Koukiadaki, A., and L. Kretsos. 2012. Opening Pandora's box: The sovereign debt crisis and labour market regulation in Greece. Industrial Law Journal 41 (3): 276-304. 
Koukouzas, N, Z. Kypritidou, G. Purser, C. A. Rochelle, C. Vasilatos, and N.

Tsoukalas. 2018. Assessment of the impact of CO2 storage in sandstone formations by experimental studies and geochemical modeling: The case of the Mesohellenic Trough, NW Greece. International Journal of Greenhouse Gas Control 71: 116-132.

Koutsovitis, P. 2012. Gabbroic rocks in ophiolitic occurrences from East Othris, Greece: petrogenetic processes and geotectonic environment implications. Mineralogy and Petrology 104 (3-4): 249-265.

Kyritsis, A., D. Voglitsis, N. Papanikolaou, S. Tselepis, C. Christodoulou, I. Gonos, and S.A. Kalogirou. 2017. Evolution of PV systems in Greece and review of applicable solutions for higher penetration levels. Renewable Energy 109: 487499.

LAGIE. 2015. Monthly report on electricity production trading system. Accessed January 19, 2020. http://www.lagie.gr/fileadmin/groups/EDRETH/DAS_Monthly_Reports/201511 DAS_Monthly_Report.pdf.

LAGIE. 2019a. Monthly reports on energy. Accessed January 19, 2020. http://www.admie.gr/deltia-agoras/miniaia-deltiaenergeias/doccat/list/Document/.

LAGIE. 2019b. RES \& CHP Monthly Statistics of Special Accounts. Accessed January 19, 2020. http://www.lagie.gr/systima-eggyimenon-timon/ape-sithya/miniaiadeltia-eidikoy-logariasmoy-ape-sithya/

LAGIE. 2019c. RES \& CHP Monthly Statistics. Accessed January 19, 2020. http://www.lagie.gr/en/feed-in-tariffs/res-chp/res-chp-monthly-statistics/

Lavidas, G. 2019. Energy and socio-economic benefits from the development of wave energy in Greece. Renewable energy 132: 1290-1300.

Lieu, J., N.A Spyridaki, R. Alvarez-Tinoco, W. Van der Gaast, A. Tuerk, and O. van Vliet. 2018. Evaluating consistency in environmental policy mixes through policy, stakeholder, and contextual interactions. Sustainability 10(6): 1896.

Lioutas, N., S. Lazarou, G. Marmidis, E. Pyrgioti, and D. Agoris. 2007. Overhead line and cable mapping of the Greek electric transmission system, for the study of transitional overvoltages, using EMTP-ATP. 15th International Symposium on High Voltage Engineering, ISH 2007, Ljubljana, Slovenia. 
Magganas, A., and P. Koutsovitis. 2015. Composition, melting and evolution of the upper mantle beneath the Jurassic Pindos ocean inferred by ophiolitic ultramafic rocks in East Othris, Greece. International Journal of Earth Sciences 104 (5): 1185-1207.

Markard, J., and B. Truffer. 2008. Technological innovation systems and the multi-level perspective: Towards an integrated framework. Research policy 37 (4): 596-615.

Martinopoulos, G., and G. Tsalikis. 2018. Diffusion and adoption of solar energy conversion systems-The case of Greece. Energy 144: 800-807.

McDowall, W. 2014. Exploring possible transition pathways for hydrogen energy: a hybrid approach using socio-technical scenarios and energy system modelling. Futures 63: 1-14.

Melikoglu, M. 2018. Current status and future of ocean energy sources: A global review. Ocean Engineering 148: 563-573.

Michas, S., V. Stavrakas, S. Papadelis, and A. Flamos. 2020. A transdisciplinary modeling framework for the participatory design of dynamic adaptive policy pathways. Energy Policy 139: 111350.

Ministry of Energy. 2018a. Annual Environmental Report Agios Dimitrios 2018. Accessed January 19, 2020. http://www.ypeka.gr/LinkClick.aspx?fileticket=RY264YS6JRE\%3d\&tabid=965 \&language $=\mathrm{el}-\mathrm{GR}$

Ministry of Energy. 2018b. Annual Environmental Report Amyntaio 2018. Accessed January 19, 2020. http://ypeka.gr/LinkClick.aspx?fileticket=0iWGOZ9O3vE\%3D\&tabid=965\&lan guage $=\mathrm{el}-\mathrm{GR}$.

Ministry of Energy. 2018c. Annual Environmental Report Kardia 2018. Accessed January 19, 2020. http://www.ypeka.gr/LinkClick.aspx?fileticket=6Bp5W875IAA\%3d\&tabid=965 \&language $=\mathrm{el}-\mathrm{GR}$

Ministry of Energy. 2018d. Annual Environmental Report Megalopoli A 2018. Accessed January 19, 2020. http://www.ypeka.gr/LinkClick.aspx?fileticket=lo7WI\%2BImUNY\%3D\&tabid $=965 \&$ language $=\mathrm{el}-\mathrm{GR}$

Ministry of Energy. 2018e. Annual Environmental Report Megalopoli B 2018. Accessed January 19, 2020. 
http://www.ypeka.gr/LinkClick.aspx?fileticket=M5\%2FtDfy\%2Bi\%2Fo\%3D\&t abid $=965 \&$ language $=\mathrm{el}-\mathrm{GR}$.

Ministry of Energy. 2018f. Annual Environmental Report Melitis 2018. Accessed January 19, 2020.

http://www.ypeka.gr/LinkClick.aspx?fileticket=3JJbqLNoFs0\%3D\&tabid=966 \&language $=\mathrm{el}-\mathrm{GR}$.

Mirek, K., and Mirek, J. 2011. Correlation between ground subsidence and induced mining seismicity, Upper Silesia Coal Basin case study. Polish Journal of Environmental Studies 20 (4A): 253-257.

Moallemi, E. A., F. J. de Haan, J. M. Webb, B. A. George, and L. Aye. 2017. Transition dynamics in state-influenced niche empowerments: Experiences from India's electricity sector. Technological Forecasting and Social Change 116: 129-141.

Mortazavi, M., and R. S. J. Sparks. 2004. Origin of rhyolite and rhyodacite lavas and associated mafic inclusions of Cape Akrotiri, Santorini: the role of wet basalt in generating calcalkaline silicic magmas. Contributions to Mineralogy and Petrology 146 (4): 397-413.

Moustakas, K., P. Parmaxidou, and S. Vakalis. 2019. Anaerobic digestion for energy production from agricultural biomass waste in Greece: Capacity assessment for the region of Thessaly. Energy: 116556.

Nádudvari, A., M. J. Fabiańska, L. Marynowski, B. Kozielska, J. Konieczyński, D. Smołka-Danielowska, and S. Ćmiel. 2018. Distribution of coal and coal combustion related organic pollutants in the environment of the Upper Silesian Industrial Region. Science of the Total Environment 628: 1462-1488.

Naftemporiki. 2019. Public Power Company: The new tender for lignite units has been launched. Naftemporiki, March 8, 2019. Accessed January 19, 2020. https://www.naftemporiki.gr/finance/story/1452097/dei-prokiruxthike-o-neosdiagonismos-gia-tis-lignitikes-monades

Nelson, R. R., and S. G. Winter. 1982. An evolutionary theory of economic change Cambridge, MA: Belknap Press.

Neuhoff, K., K. K. Martinez, and M. Sato. 2006. Allocation, incentives and distortions: the impact of EU ETS emissions allowance allocations to the electricity sector. Climate Policy 6 (1): 73-91.

New Climate Institute. 2019. De-risking Onshore Wind Investment - Case Study: South East Europe. Study on behalf of Agora Energiewende. www.agora- 
energiewende.de Accessed April 2, 2020 https://www.agoraenergiewende.de/fileadmin2/Projekte/2019/Derisking SEE/161 Unlocking SEE EN WEB.pdf

Newman, H. R. 2013. The mineral industry of Greece. Minerals Yearbook-Area Reports: International Review: 2011, Europe and Central Eurasia 3: 14.

Nguyen, T. T., T. T. Nguyen, V. N. Hoang, C. Wilson, and S. Managi. 2019. Energy transition, poverty and inequality in Vietnam. Energy Policy 132: 536-548.

Nikas, A., H. Doukas, J. Lieu, R. A. Tinoco, V. Charisopoulos, and W. van der Gaast. 2017. Managing stakeholder knowledge for the evaluation of innovation systems in the face of climate change. Journal of Knowledge Management 21 (5):10131034

Nikas, A., E. Ntanos, and H. Doukas. 2019. A semi-quantitative modelling application for assessing energy efficiency strategies. Applied Soft Computing 76: 140-155.

Nikas, A., N. Gkonis, A. Forouli, E. Siskos, A. Arsenopoulos, A. Papapostolou, E. Kanellou, C. Karakosta, and H. Doukas. 2019. From near-term actions to longterm pathways-risks and uncertainties associated with the national energy efficiency framework. In Narratives of Low-Carbon Transitions, 180-197.

Nikas, A., V. Stavrakas, A. Arsenopoulos, H. Doukas, M. Antosiewicz, J. WitajewskiBaltvilks, and A. Flamos. 2018. Barriers to and consequences of a solar-based energy transition in Greece. Environmental Innovation and Societal Transitions.

Nikolaidis, G., A. Karaolia, A. Matsikaris, A. Nikolaidis, M. Nicolaides, and G.C. Georgiou. 2019. Blue energy potential analysis in the Mediterranean. Frontiers in Energy Research 7 (62): 12.

Nikolaou, A., and D. Diakoulaki. 2003. Life Cycle Assessment of a bio-electricity system in Greece. Proceedings of the 8th International Conference on Environmental Science and Technology, Lemnos Island, Greece, 8-10 September 2003. Full paper vol. B.

Noll, D., D. Wiedenhofer, A. Miatto, and S.J. Singh. 2019. The expansion of the built environment, waste generation and EU recycling targets on Samothraki, Greece: An island's dilemma. Resources, Conservation and Recycling 150: 104405.

Nykvist, B., and L. Whitmarsh. 2008. A multi-level analysis of sustainable mobility transitions: Niche development in the UK and Sweden. Technological forecasting and social change 75 (9): 1373-1387. 
Oikonomou, V., A. Flamos, D. Zeugolis, and S. Grafakos. 2012. A qualitative assessment of EU energy policy interactions. Energy Sources, Part B: Economics, Planning, and Policy 7(2): 177-187.

Oikonomou, V., A. Flamos, and S. Grafakos. 2014. Combination of energy policy instruments: creation of added value or overlapping? Energy Sources, Part B: Economics, Planning, and Policy 9(1): 46-56.

Orfanos, N., D. Mitzelos, A. Sagani, and V. Dedoussis. 2019. Life-cycle environmental performance assessment of electricity generation and transmission systems in Greece. Renewable energy 139: 1447-1462.

Pantusa, D., and G. R. Tomasicchio. 2019. Large-scale offshore wind production in the Mediterranean Sea. Cogent Engineering 6 (1): 1661112.

Papada, L., N. Katsoulakos, I. Doulos, D. Kaliampakos, and D. Damigos. 2019. Analyzing energy poverty with Fuzzy Cognitive Maps: A step-forward towards a more holistic approach. Energy Sources, Part B: Economics, Planning, and Policy 14 (5): 159-182.

Papadelis, S., A. Flamos, and J. Psarras. 2013. A framework to address uncertainties in energy policy formulation. Energy Sources, Part B: Economics, Planning, and Policy 8(3): 270-278.

Papadelis, S., V. Stavrakas, and A. Flamos. 2016. What do capacity deployment rates tell us about the efficiency of electricity generation from renewable energy sources support measures in Greece?. Energies 9(1): 38.

Papadopoulos, M. 2018. The establishment and development of Public Power Company. Kathimerini, April 16, 2018. Accessed January 19, 2020. https://www.kathimerini.gr/959053/gallery/epikairothta/ellada/h-idrysh-kaianapty3h-ths-deh.

Papagiannis, A., D. Roussos, M. Menegaki, and D. Damigos. 2014. Externalities from lignite mining-related dust emissions. Energy Policy 74: 414-424.

RAE. 2001. Map of power stations and transmission network. Accessed January 19, 2020. rae.gr/old/sub3/3B/3b3.htm.

RAE. 2013. Thermal power plants in the interconnected system. Accessed January 19, 2020.

http://www.rae.gr/site/file/categories_new/about_rae/factsheets/2013/mods/0711 $2013 ? \mathrm{p}=$ file $\& \mathrm{i}=0$. 
RAE. 2014. Non-interconnected Islands. Accessed January 19, 2020.

www.rae.gr/site/categories_new/electricity/market/mdn.cs.

RAE. 2019a. Electricity Supply \& Competition. Accessed January 19, 2020.

http://www.rae.gr/site/categories_new/consumers/know_about/electricity/compe tition.csp

RAE. 2019b. The Greek energy system - Natural Gas. Accessed January 19, 2020. http://www.rae.gr/old/sub3/3B/3b2.htm

Rip, A., and R. Kemp. 1998. Technological change. In Human choice and climate change, Vol. 2, 327-399. Columbus, OH: Battelle Press.

Rogge, K. S., B. Pfluger, and F. W. Geels. 2018. Transformative policy mixes in sociotechnical scenarios: The case of the low-carbon transition of the German electricity system (2010-2050). Technological Forecasting and Social Change.

Roinioti, A., and C. Koroneos. 2019. Integrated life cycle sustainability assessment of the Greek interconnected electricity system. Sustainable Energy Technologies and Assessments 32: 29-46.

Roumpos, C., and E. Papacosta. 2013. Strategic mine planning of surface mining projects incorporating sustainability concepts. Proceedings, 6th International Conference on Sustainable Development in the Minerals Industry (SDIMI 2013), Milos Island, Greece, June.

Roupas, C., A. Flamos, and J. Psarras, J. 2011. Comparative analysis of EU member countries vulnerability in oil and gas. Energy Sources, Part B: Economics, Planning, and Policy 6(4): 348-356.

Saccani, E., and A. Photiades. 2004. Mid-ocean ridge and supra-subduction affinities in the Pindos ophiolites (Greece): implications for magma genesis in a forearc setting. Lithos 73 (3-4): 229-253.

Sachs, J. D. 2012. From millennium development goals to sustainable development goals. The Lancet 379 (9832): 2206-2211.

Sachs, J., G. Schmidt-Traub, C. Kroll, G. Lafortune, and G. Fuller. 2019. Sustainable development report 2019. Bertelsmann Stiftung and Sustainable Development Solutions Network (SDSN): New York, NY, USA.

Sagani, A., M. Hagidimitriou, and V. Dedoussis. 2019. Perennial tree pruning biomass waste exploitation for electricity generation: The perspective of Greece. Sustainable Energy Technologies and Assessments 31: 77-85. 
Sakellaridis, N., J. Mantzaris, C. Nakos, G. Giannakidis, and K. Tigas. 2011. Hellenic power generation system: Towards meeting the national targets up to 2020. 2011 10th International Conference on Environment and Electrical Engineering. Samara, C., G. Argyropoulos, T. Grigoratos, A. Kouras, E. Manoli, S. Andreadou, F. Pavloudakis, and C. Sahanidis. 2018. Chemical characterization and receptor modeling of PM 10 in the surroundings of the opencast lignite mines of Western Macedonia, Greece. Environmental Science and Pollution Research 25 (13): 12206-12221.

Sari, R., E. Voyvoda, M. Lacey-Barnacle, E. Karababa, C. Topal, and D. Islambay. 2017. Energy Justice-a Social Sciences and humanities Cross-Cutting Theme Report, SHAPE ENERGY, Cambridge.

Schot, J. 1998. The usefulness of evolutionary models for explaining innovation. The case of the Netherlands in the nineteenth century. History and Technology, an International Journal 14 (3): 173-200.

Sebastián, F., J. Royo, and M. Gómez. 2011. Cofiring versus biomass-fired power plants: GHG (Greenhouse Gases) emissions savings comparison by means of LCA (Life Cycle Assessment) methodology. Energy 36 (4): 2029-2037.

Smith, A. 2007. Translating sustainabilities between green niches and socio-technical regimes. Technology analysis \& strategic management 19 (4): 427-450.

Sorman, A. H., X. García-Muros, C. Pizarro-Irizar, and M. González-Eguino. 2020. Lost (and found) in Transition: Expert stakeholder insights on low-carbon energy transitions in Spain. Energy Research \& Social Science 64: 101414.

Soukissian, T., F. Karathanasi, P. Axaopoulos, E. Voukouvalas, and V. Kotroni. 2018. Offshore wind climate analysis and variability in the Mediterranean Sea. International Journal of Climatology 38 (1): 384-402.

Spilanis, G. 1999. Summary of the Report on the Regional Development Plan 20002006. Island Area Development. University of the Aegean. Accessed January $19,2020$. http://www1.aegean.gr/lid/internet/elliniki_ekdosi/Dimosieuseis/EspaceInsulaire.htm

Spiliotis, E., A. Arsenopoulos, E. Kanellou, J. Psarras, and P. Kontogiorgos. 2020. A multi-sourced data based framework for assisting utilities identify energy poor households: a case-study in Greece. Energy Sources, Part B: Economics, Planning, and Policy: 1-23. 
Stavrakas, V., and A. Flamos. 2020. A modular high-resolution demand-side management model to quantify benefits of demand-flexibility in the residential sector. Energy Conversion and Management 205: 112339.

Stavrakas, V., S. Papadelis, and A. Flamos. 2019. An agent-based model to simulate technology adoption quantifying behavioural uncertainty of consumers. Applied Energy 255: 113795.

Stouraiti, C., I. Pantziris, C. Vasilatos, C. Kanellopoulos, P. Mitropoulos, P. Pomonis, R. Moritz, and M. Chiaradia. 2017. Ophiolitic remnants from the upper and intermediate structural unit of the Attic-Cycladic Crystalline Belt (Aegean, Greece): Fingerprinting geochemical affinities of magmatic precursors. Geosciences 7 (1): 14.

Strantzali, E., K. Aravossis, and G. A. Livanos. 2017. Evaluation of future sustainable electricity generation alternatives: The case of a Greek island. Renewable and Sustainable Energy Reviews 76: 775-787.

Swain, R.B., and A. Karimu. 2020. Renewable electricity and sustainable development goals in the EU. World Development 125: 104693.

Tasianas, A., and N. Koukouzas. 2016. CO2 storage capacity estimate in the lithology of the Mesohellenic Trough, Greece. Energy Procedia 86: 334-341.

TEE. 2008. Electricity production from fossil fuels. Accessed January 19, 2020. library.tee.gr/digital/m2483/m2483_bonataki.pdf.

TEE. 2010. The Hydroelectric power production of PPC S.A. Accessed January 19, 2020. http://library.tee.gr/digital/m2483/m2483_argirakis.pdf.

Tourkolias, C., S. Mirasgedis, D. Damigos, and D. Diakoulaki. 2009. Employment benefits of electricity generation: A comparative assessment of lignite and natural gas power plants in Greece. Energy Policy 37 (10): 4155-4166.

Tranberg, B., O. Corradi, B. Lajoie, T. Gibon, I. Staffell, and G. B. Andresen. 2019. Real-time carbon accounting method for the European electricity markets. Energy Strategy Reviews 26: 100367.

Tsirambides, A., and A. Filippidis. 2012. Metallic mineral resources of Greece. Open Geosciences 4 (4): 641-650.

Tsirogiannis, E., P. Angelidis, and N. Kotsovinos. 2019. Hydrodynamic Circulation under Tide Conditions at the Gulf of Evoikos, Greece. Computational Water, Energy, and Environmental Engineering 8 (03): 57. 
Tzogopoulos, G. N. 2017. Greece, Israel, and China's Belt and Road Initiative. Mideast Security and Policy Studies No. 139, The Begin-Sadat Center for Strategic Studies Bar-Ilan University.

Upham, P., P. Kivimaa, P. Mickwitz, and K. Åstrand, K. 2014. Climate policy innovation: a sociotechnical transitions perspective. Environmental Politics 23(5): 774-794.

Vagiona, D., and M. Kamilakis. 2018. Sustainable Site Selection for Offshore Wind Farms in the South Aegean-Greece. Sustainability 10 (3): 749.

Van der Gaast, W., V. Oikonomou, and A. Flamos. 2013. Domestic offsets in practice: Modalities and implications. Energy Sources, Part B: Economics, Planning, and Policy 8(2): 144-153.

Van Driel, H., and J. Schot. 2005. Radical innovation as a multilevel process: introducing floating grain elevators in the port of Rotterdam. Technology and Culture 46 (1): 51-76.

van Sluisveld, M. A., A. F. Hof, S. Carrara, F. W. Geels, W. Nilsson, K. Rogge, K. Turnheim, and D.P. van Vuuren. 2018. Aligning integrated assessment modelling with socio-technical transition insights: An application to low-carbon energy scenario analysis in Europe. Technological Forecasting and Social Change: 119177.

van Soest, H. L., D. P. van Vuuren, J. Hilaire, J. C. Minx, M. J.H.M. Harmsen, V. Krey, A. Popp, K. Riahi, and G. Luderer. 2019. Analysing interactions among Sustainable Development Goals with Integrated Assessment Models. Global Transitions 1: 210-225.

Vapur, H., and S. Top. 2017. Comparison of coal-based energy production with other resources to determine an effective method in Turkey. Energy Sources, Part B: Economics, Planning, and Policy 12 (3): 282-288.

Vasilakos, N. 2019. Energy transition challenges and development priorities for the Greek energy sector in the coming decade. Robert Schuman Centre for Advanced Studies Research Paper No. RSCAS 37.

Vatalis, K. I., A. Laaksonen, G. Charalampides, and N. P. Benetis. 2012. Intermediate technologies towards low-carbon economy. The Greek zeolite CCS outlook into the EU commitments. Renewable and Sustainable Energy Reviews 16 (5): 33913400. 
Verbong, G., and F. W. Geels. 2007. The ongoing energy transition: lessons from a socio-technical, multi-level analysis of the Dutch electricity system (19602004). Energy policy 35 (2): 1025-1037.

Weaver, P. M., and J. Rotmans. 2006. Integrated sustainability assessment: what is it, why do it and how? International journal of innovation and sustainable development 1 (4): 284-303.

World Commission on Dams. 2000. Dams and development: A new framework for decision-making. New York: World Commission on Dams.

WSA. 2011. Methodology Report - Life Cycle Inventory Study for Steel Products. World Steel Association, Brussels.

Wu, Y., R. Li, L. Cui, Y. Meng, H. Cheng, and H. Fu. 2020. The high-resolution estimation of sulfur dioxide (SO2) concentration, health effect and monetary costs in Beijing. Chemosphere 241: 125031.

WWF. 2019. Greece commits to phase out lignite and single use plastics. Accessed January 19, 2020. https://www.wwf.gr/en/news/2311-greece-commits-to-phaseout-lignite-and-single-use-plastic.

Yücel, G. 2010. Analyzing Transition Dynamics: The Actor-Option Framework for Modelling Socio-Technical Systems. Doctoral Thesis, TU Delft.

Zafeiratou, E., and Spataru, C. 2015. Investigation of high renewable energy penetration in the island of Syros following the interconnection with the national grid system. Energy Procedia 83: 237-247.

Zafeiratou, E., and C. Spataru. 2017. Potential economic and environmental benefits from the interconnection of the Greek islands. International Journal of Global Warming 13 (3/4): 426-458.

Zafeiratou, E., and Spataru, C. 2019. Long Term analysis of submarine transmission grid extensions between the Greek islands and the mainland. In 2019 International Conference on Smart Energy Systems and Technologies (SEST): 16. IEEE.

Zevgolis, I. E., A. V. Deliveris, and N. C. Koukouzas. 2019. Slope failure incidents and other stability concerns in surface lignite mines in Greece. Journal of Sustainable Mining 18 (4): 182-197. 